Формирование коморбидности у пациентов с тяжелым повреждением мозга и исходом в хроническое критическое состояние (обзор)

\author{
А. Л. Парфенов ${ }^{1}$, М. В. Петрова ${ }^{1,2}$, И. М. Пичугина ${ }^{1}$, Е. В. Лугинина ${ }^{1}$ \\ ${ }_{1}^{1}$ Федеральный научно-клинический центр реаниматологии и реабилитологии, \\ Россия, 141534, Московская область, Солнечногорский район, д. Лыткино, д. 777 \\ 2 Российский университет дружбы народов, \\ Россия, 117198, г. Москва, ул. Миклухо-Маклая, д. 6
}

\title{
Comorbidity Development in Patients with Severe Brain Injury Resulting in Chronic Critical Condition (Review)
}

\author{
Alexander L. Parfenov ${ }^{1}$, Marina V. Petrova ${ }^{1,2}$, Irina M. Pichugina ${ }^{1}$, Elena V. Luginina ${ }^{1}$ \\ ${ }^{1}$ Federal Research and Clinical Center of Intensive Care Medicine and Rehabilitology, \\ 777 Lytkino 141534, Solnechnogorsk district, Moscow region, Russia \\ ${ }^{2}$ Peoples' Friendship University of Russia, \\ 6 Miklukho-Maclaya Str., 117198 Moscow, Russia
}

\begin{abstract}
Для цитирования: А. Л. Парфенов, М. В. Петрова, И. М. Пичугина, Е. В. Лугинина. Формирование коморбидности у пациентов с тяжелым повреждением мозга и исходом в хроническое критическое состояние (обзор). Общая реаниматология. 2020; 16 (4): 72-89. DOI: 10.15360/1813-9779-2020-4-72-89 [На русск. и англ.]

For citation: Alexander L. Parfenov, Marina V. Petrova, Irina M. Pichugina, Elena V. Luginina. Comorbidity Development in Patients with Severe Brain Injury Resulting in Chronic Critical Condition (Review). Obshchaya Reanimatologiya = General Reanimatology. 2020; 16 (4): 72-89. DOI: 10.15360/1813-9779-2020-4-72-89 [In Russ. and Engl.]
\end{abstract}

\section{Резюме}

Достижения интенсивной терапии позволяют пережить острое критическое состояние, в результате чего создается растущая популяция пациентов в хроническом критическом состоянии с длительной зависимостью от методов интенсивной терапии. Указанные пациенты составляют 5-10\% от всех пациентов с острой дыхательной недостаточностью, требуют непропорционально высокой доли ресурсов отделений реанимации и интенсивной терапии при общей выживаемости в течение года в 40-50\%.

Цель обзора. Выявить влияние коморбидных осложнений на течение и исходы пациентов с тяжелыми повреждениями головного мозга.

Критериями отбора 96 источников являлись сведения, характеризующие клиническую (синдромальную) модель пациента, в которой рассмотрен синдром пациента с посткоматозными нарушениями сознания различной этиологии. Данная модель учитывает стадии и фазы синдрома, а также перечень коморбидных заболеваний, которые определяют течение и исход заболевания.

В перечень источников вошли работы, посвященные проблеме коморбидности, у пациентов с повреждениями и заболеваниями головного мозга (инсульты, последствия тяжелой черепно-мозговой травмы и операций на головном мозге).

Рассмотрены источники, отражающие наиболее значимые механизмы последовательного формирования коморбидных заболеваний. К ним относятся: нарушения метаболизма с последующим развитием белково-энергетической недостаточности; коморбидные заболевания желудочно-кишечного тракта. Определена роль микробиома в формировании коморбидности у пациентов в хроническом критическом состоянии.

Заключение. Формирование коморбидности начинается с момента повреждения головного мозга и продолжается до стойкой стабилизации состояния или до полиорганной недостаточности и летального исхода. Своевременное выявление и коррекция коморбидных состояний позволит оптимизировать лечение и повысить эффективность реабилитационных мероприятий у пациентов с тяжелыми повреждениями головного мозга.

Ключевые слова: коморбидность; хроническое критическое состояние; гиперметаболизм; гиперкатаболизм; микробиом

\section{Summary}

Advances in intensive care have enabled patients to survive an acute critical condition, producing a growing population of patients in a chronic critical condition with long-term dependence on intensive care. These pa-

Адрес для корреспонденции:

Александр Леонидович Парфенов

E-mail: alpar45@mail.ru
Correspondence to:

Alexandtr L. Parphenov

E-mail: alpar45@mail.ru 
tients make up $5-10 \%$ of all patients with acute respiratory failure and require a disproportionate share of resources in the intensive care units, with an overall yearly survival rate of $40-50 \%$.

The aim of review is to identify the impact of comorbid complications on the course and outcome of patients with severe brain injury.

Ninety-six sources were selected according to the data characterizing the clinical (syndromic) model of the patient with consciousness disorders after coma of different etiologies. This model takes into account the stages and phases of the syndrome as well as a number of comorbid conditions that determine the course and outcome of the disease.

The list of sources includes papers addressing the issues of comorbidity in patients with brain injury and conditions such as strokes, consequences of severe brain injury and brain surgery.

The sources reflecting the most significant mechanisms of consistent development of comorbidities were examined. These include metabolic disorders with subsequent protein and energy deficiency and comorbidities of the gastrointestinal tract. The role of microbiome in the development of comorbidity in patients in chronic critical condition was also identified.

Conclusion. The comorbidity development starts from the moment of brain injury and extends until sustained stabilization or multi-organ failure and death. Timely detection and correction of comorbidities allows optimizing treatment and increasing efficiency of rehabilitation in patients with severe brain injury.

Keywords: comorbidity; chronic critical condition; hypermetabolism; hypercatabolism; microbiome

DOI:10.15360/1813-9779-2020-4-72-89

\section{Введение}

Количество хронических критических состояний (ХКС) за последние десятилетия удвоилось и может удвоиться в течение следующего десятилетия, а общая выживаемость в течение года пациентов с ХКС находится в пределах от 40 до 50\%. [1]. Как правило, указанные пациенты имеют тяжелое повреждение головного мозга (травма, инсульт, интоксикация, гипоксия), пережили острейшую фазу заболевания с исходом в вегетативное состояние или в состояние малого сознания и нуждаются в особых подходах к продолжительному интенсивному и реабилитационному лечению [2].

Тяжелые повреждения головного мозга сопровождаются каскадом патологических реакций не только в головном мозге [3] (отек мозга и его дислокации, нарушения церебральной гемодинамики, воспалительные осложнения и т. д.). В патологический процесс последовательно и закономерно вовлекается сердечнососудистая система, органы дыхания, пищеварения, водного обмена, гормональной регуляции и т. д. Нарушения трофики, иммунитета, присоединение гнойно-воспалительных осложнений замыкают круг патологических реакций, и часто приводят к летальному исходу [4-6].

Формирование коморбидного синдрома у пациентов в хроническом критическом состоянии тесно связано с белково-энергетической недостаточностью (БЭН), в сочетании с нарушениями деятельности желудочно-кишечного тракта (ЖКТ), гипоальбуминемией, препятствующей адекватной детоксикации, а также с глубокими нарушениями микробиома.

Цель обзора - выявить влияние коморбидных осложнений на течение и исходы пациентов с тяжелыми повреждениями головного мозга.

\section{Introduction}

Chronic critical illness (CCI) have doubled in recent decades and could double over the next decade, and the overall survival rate for patients with CCIs ranges from 40 to $50 \%$ during the year [1]. Typically, these patients have severe brain damage (trauma, stroke, intoxication, hypoxia), have experienced an acute phase of the disease resulting in vegetative or low consciousness state and require special approaches to long-term intensive and rehabilitation treatment [2].

Severe brain damage is associated with a cascade of pathological reactions in the brain (brain swelling and dislocation, cerebral circulation disorders, inflammatory complications, etc.) [3] as well as elsewhere in the body. The pathological process involves consistently the cardiovascular, respiratory, digestive systems, fluid and electrolyte balance, hormonal regulation, etc. Abnormal metabolism, immunity, purulent and inflammatory complications complete the vicious circle of pathological reactions and often lead to death [4-6].

Comorbidity in patients in chronic critical condition is closely related to protein-energy deficiency (PED) combined with gastrointestinal tract (GIT) dysfunction, hypoalbuminemia, which prevents adequate detoxication, and severe microbiome disorders.

The aim of our review is to investigate the impact of comorbid complications on the course of disease and outcome in patients with severe brain damage.

\section{Patient Model for Severe Brain Damage Resulting in Chronic Critical Condition}

The patient model is defined as «...a constructed description of an object (disease, syndrome, clinical situation), determining a set of 


\section{Модель пациента при тяжелом повреждении мозга с исходом в хроническое критическое состояние}

Под моделью пациента понимают «...сконструированное описание объекта (заболевание, синдром, клиническая ситуация), регламентирующее совокупность клинических или ситуационных характеристик, выполненное на основе оптимизации выбора переменных (осложнение, фаза, стадия заболевания) с учетом наибольшего их влияния на исход и значимых причинно-следственных связей, определяющее возможность и необходимость описания технологии оказания медицинской помощи» [7].

Различают нозологическую синдромальную и ситуационную модели пациентов. Для пациентов с тяжелым повреждением мозга с последующим исходом в хроническое критическое состояние и посткоматозное нарушение сознания (ПКНС) предложена синдромальная модель, включающая перечень коморбидных заболеваний, характерных для данной модели (таблица).

Установлено, что ПКНС представляют собой следующие непосредственно после комы и сменяющие друг друга синдромы, начинающиеся с первого открывания глаз пациента и заканчивающиеся появлением контакта с пациентом (чаще всего в виде отчетливого выполнения инструкций). К ПКНС относят вегетативный статус, минимальное состояние сознания и акинетический мутизм. Если стойкое (персистирующее) вегетативное состояние относится в настоящее время к состояниям, не поддающимся излечению, то при минимальном уровне сознания и акинетическом мутизме возможен положительный исход. В тоже время, отсутствие правильно организованного лечения приводит к исходу в стойкое вегетативное состояние всю группу пациентов с ПКНС.

Формирование модели происходит с первых минут после повреждения мозга в результате травмы, инсульта, после перенесенных операций или от других, повреждающих мозг причин. Различают первичные и вторичные повреждения мозга. Первичное повреждение возникает в результате непосредственного воздействия на мозг, и вторичное, вследствие сложных и многообразных механизмов, запускаемых впоследствии. Вторичные повреждения мозга подразделяют на внутричерепные (сдавление мозга внутричерепными гематомами; нарушения гемо- и ликвороциркуляции, набухание мозга вследствие отека, гиперемии или венозного полнокровия; повышение внутричерепного давления; развитие инфекции мозга, его оболо- clinical or situational characteristics, performed based on optimized choice of variables (complication, phase, stage of the disease) taking into account their greatest influence on the outcome and significant causal relations, indicating the possibility and necessity to describe the technology of medical care» [7].

A distinction is made between syndromal and situational models of patients. For patients with severe brain damage resulting in chronic critical condition and post-comatose consciousness disorder (PCCD), a syndromal model has been proposed, which includes a list of comorbid diseases typical for this model (table).

PCCD include syndromes that immediately follow coma, in a sequence starting with the first opening of the patient's eyes and ending with the established patient contact (most often manifesting as obeying of commands). PCCD comprise vegetative status, minimal state of consciousness and akinetic mutism. While the persistent vegetative state currently is considered incurable, a positive outcome in minimal consciousness level and akinetic mutism is possible. At the same time, the inadequate treatment results in a stable vegetative state for the whole group of patients with PCCD.

The model can de generated starting from the first minutes after the brain trauma, stroke, surgery or other events causing brain damage. Brain damage is divided into primary and secondary. Primary damage occurs as a result of direct impact on the brain, and secondary damage is a result of complex and diverse mechanisms initiated later. Secondary brain damage is categorized into intracranial (compression of brain by intracranial hematomas; blood and liquor circulation disorders; brain swelling due to edema, hyperemia or venous congestion; increase in intracranial pressure; development of infection of the brain and its membranes) and extracranial (hypoxemia and anemia; arterial hypotension; hyper- or hypocapnia; hypo- or hypernatremia; hypo- or hyperglycemia, hyperthermia, endogenous intoxication, etc.), which aggravates the primary damage.

The severity of the patient's condition, adaptation and recovery capabilities (rehabilitation potential) close depend not only on the primary brain damage, but also on successful prevention and treatment of secondary damage. Low consciousness and prolonged lung ventilation represent the acute and subacute phases of the disease, when the primary damage sequelae have already appeared and the secondary damage is under way.

The patient syndrome model is based on the pathogenetic principle without taking into account the etiology and includes different stages of the continuum of consciousness recovery after the coma.

Following severe brain damage, CCI can be considered as a patient model characterized by var- 
Синдромальная модель пациента с тяжелым повреждением мозга и исходом в хроническое критическое состояние и посткоматозное нарушение сознания.

\begin{tabular}{|c|c|}
\hline Синдром & ПКНС различной этиологии \\
\hline \multirow{11}{*}{$\begin{array}{l}\text { Стадия } \\
\text { синдрома }\end{array}$} & Вегетативное состояние (ВС) \\
\hline & Состояние минимального сознания (СМС) \\
\hline & Акинетический мутизм (АМ) \\
\hline & Мутизм (M) \\
\hline & Синдром деэфферентации (СД) \\
\hline & Синдром стойкого \\
\hline & неврологического дефекта (ССНД) \\
\hline & Синдром умеренного \\
\hline & неврологического дефекта (СУНД) \\
\hline & Синдром минимального \\
\hline & неврологического дефекта (СМНД) \\
\hline \multirow{5}{*}{$\begin{array}{l}\text { Фазы } \\
\text { синдрома }\end{array}$} & Стабилизация процесса \\
\hline & Ремиссия \\
\hline & Рецидив \\
\hline & Прогредиентное течение \\
\hline & Остаточные явления \\
\hline \multirow[t]{26}{*}{$\begin{array}{l}\text { Коморбидные } \\
\text { заболевания }\end{array}$} & Наименование \\
\hline & Недостаточность питания \\
\hline & $\begin{array}{l}\text { Тяжелая белково-энергети- } \\
\text { ческая недостаточность } \\
\text { неуточненная }\end{array}$ \\
\hline & $\begin{array}{ll}\text { Последствия недостаточности } & \text { E64 } \\
\text { питания и недостатка других } & \\
\text { питательных веществ } & \end{array}$ \\
\hline & Другие нарушения регуляции \\
\hline & $\begin{array}{l}\text { глюкозы и внутренней секреции } \\
\text { поджелудочной железы }\end{array}$ \\
\hline & $\begin{array}{l}\text { Другие нарушения водно-солевого E87 } \\
\text { обмена или кислотно-щелочного } \\
\text { равновесия }\end{array}$ \\
\hline & Анемии, связанные с питанием D50-D53 \\
\hline & Болезни пищевода, желудка K20-К31 \\
\hline & и двенадцатиперстной кишки \\
\hline & $\begin{array}{l}\text { Другие бактериальные кише- } \\
\text { чные инфекции (А04) }\end{array}$ \\
\hline & $\begin{array}{l}\text { Нарушения всасывания } \\
\text { в кишечнике }\end{array}$ \\
\hline & Другие острые респираторные J20-J22 \\
\hline & $\begin{array}{l}\text { инфекции нижних дыхательных } \\
\text { путей }\end{array}$ \\
\hline & $\begin{array}{l}\text { Хронические болезни нижних } \\
\text { дыхательных путей }\end{array}$ \\
\hline & $\begin{array}{l}\text { Гнойные и некротические J85-J86 } \\
\text { состояния нижних дыхательных } \\
\text { путей }\end{array}$ \\
\hline & Другие болезни плевры \\
\hline & $\begin{array}{l}\text { Респираторные нарушения } \\
\text { после медицинских процедур, } \\
\text { не классифицированные } \\
\text { в других рубриках }\end{array}$ \\
\hline & $\begin{array}{l}\text { Дыхательная недостаточность, } \\
\text { не классифицированная } \\
\text { в других рубриках }\end{array}$ \\
\hline & Другие болезни \\
\hline & мочевой системы \\
\hline & Легочная эмболия \\
\hline & Острый инфаркт миокарда \\
\hline & Отек мозга \\
\hline & Цереброваскулярные болезни I60-I69 \\
\hline & $\begin{array}{l}\text { Расстройства личности и пове- } \\
\text { дения, обусловленные болезнью, } \\
\text { повреждением или дисфункцией } \\
\text { головного мозга }\end{array}$ \\
\hline $\begin{array}{l}\text { Нозологичес- } \\
\text { кая форма }\end{array}$ & $\begin{array}{l}\text { Последствия тяжелой черепно-мозговой } \\
\text { травмы, состояние после оперативного } \\
\text { лечения новообразований головного } \\
\text { мозга, сосудистой патологии, последствия } \\
\text { геморрагических и ишемических инсультов. }\end{array}$ \\
\hline
\end{tabular}

Syndromic model of a patient with severe brain damage resulting in chronic critical condition and post-comatose consciousness disorders.

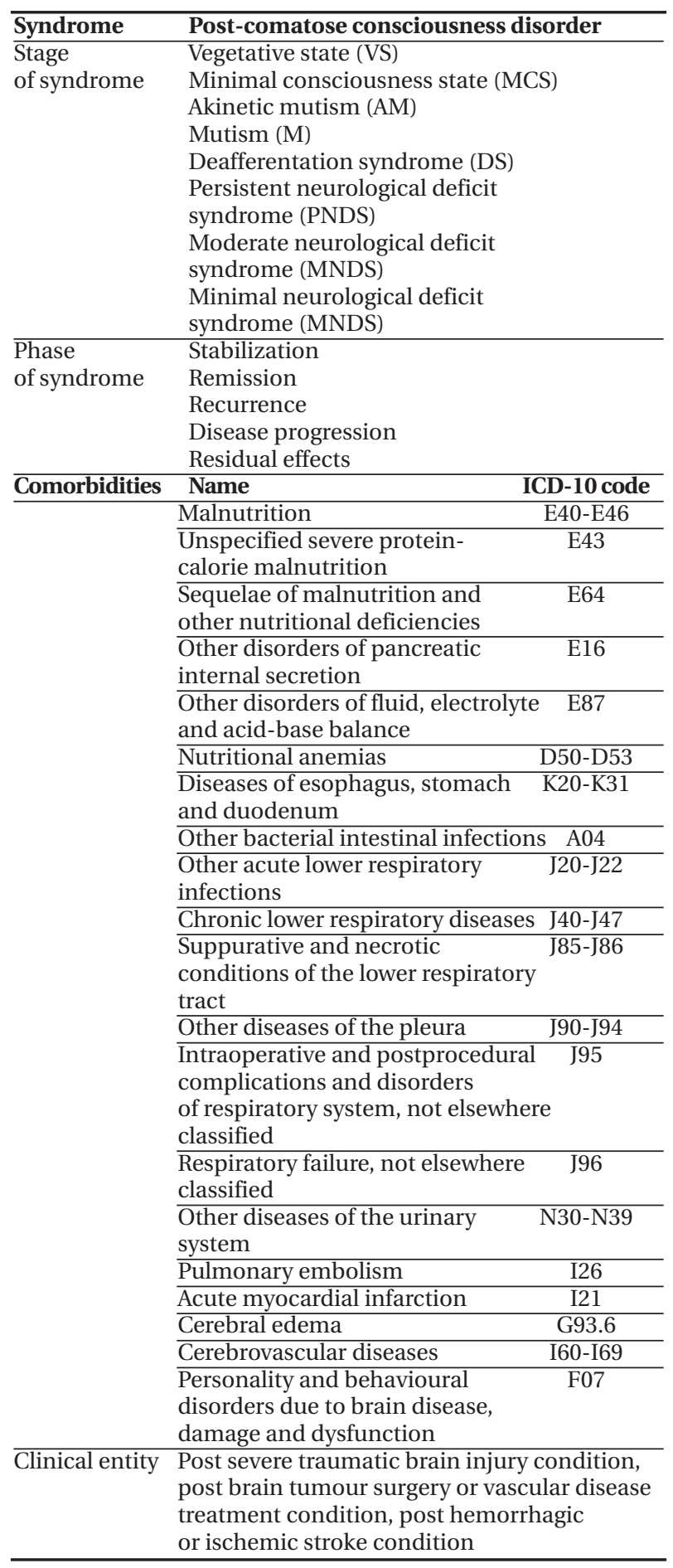

ious comorbidities and multimorbidity. Accompanying diseases significantly delay the recovery, considerably increase treatment costs and, in most cases, are the main cause of death.

\section{Multimorbidity and Comorbidity: General Concepts and Definition}

The combination of complications accompanying the main disease is termed comorbidity. The concept of «comorbidity» was suggested by an 
чек) и внечерепные (гипоксемия и анемия; артериальная гипотензия; гипер-, гипокапния; гипо-, гипернатриемия; гипо-, гипергликемия, гипертермия, эндогенная интоксикация и др.), которые усугубляют первичное повреждение.

Тяжесть состояния пациентов, возможности адаптации и восстановления (реабилитационный потенциал) находятся в тесной связи не только с особенностями первичного повреждения мозга, но и с успехами по предупреждению и лечению вторичных повреждений. Исход в низкий уровень сознания и длительную искусственную вентиляцию легких представляет собой острую и подострую фазу заболевания, когда последствия первичного повреждения уже сформированы, а вторичные повреждения находятся в фазе развития.

Выделение синдромальной модели пациентов основано на патогенетическом принципе без учета этиологии процесса и включает разные стадии континуума восстановления сознания после перенесенной комы.

Исход пациента в хроническое критическое состояние после тяжелого повреждения мозга является моделью пациента, которая характеризуется большим перечнем сопутствующих (коморбидных и полиморбидных) заболеваний. Указанные заболевания значительно продлевают течение восстановительного процесса, существенно увеличивают затраты на лечение и, в большинстве случаев, являются основной причиной летального исхода.

\section{Полиморбидность и коморбидность. Понятия и определения}

Сочетание осложнений, сопровождающих основную патологию, обозначают как коморбидность. Понятие «коморбидность» предложил американский врач A. R. Feinstein еще в 1970 году [8], однако до настоящего времени нет достаточно четкого определения понятия поли- и коморбидности. Коморбидность определяют как наличие одновременно нескольких заболеваний, связанных единым патогенетическим механизмом [9, 10], а полиморбидность - как наличие не связанных между собой заболеваний $[11,12]$.

В качестве синонимов используют следующие определения: полиморбидность, мультиморбидность, мультифакториальные заболевания, полипатия, соболезненность, двойной диагноз, плюрипатология. Такое разнообразие терминологии свидетельствует об отсутствии единого научного подхода к определению термина коморбидности, что требует дальнейшего изучения этого явления.

Проблеме полиморбидности посвящено большое количество исследований. Многие
American physician A.R. Feinstein as early as in 1970 [8], however, the definition of multi- and comorbidity is not yet clear enough. Comorbidity is defined as the presence of several diseases which share the same pathogenetic mechanism $[9,10]$, and multimorbidity is defined as the presence of unrelated diseases $[11,12]$.

The following definitions are used as synonyms: polymorbidity, multimorbidity, multifactorial diseases, polypathy, double diagnosis, pluripathology. This variety of terminology indicates that there is no single scientific approach to the definition of the term comorbidity, which requires further study of this problem.

Numerous studies have been devoted to the problem of multimorbidity. Many researchers believe that it cannot be caused by a random combination of observed disorders, but rather based on a strict hierarchy of mechanisms determining the variety and integrity of pathological manifestations. Studies of multimorbidity in geriatrics, cardiovascular, gastrointestinal, mental, neurological and other diseases are most widely represented in the scientific literature $[13,14]$.

Severe brain damage resulting in chronic critical illness can be considered a special clinical patient model. Changes in the brain after its damage in injury or disease are associated with functional and morphological abnormalities in internal organs, which create a basis for the consistent development of a number of comorbid diseases [15]. These changes form a vicious pathological circle that prevents stabilization and restoration of cerebral functions [16].

Insufficient scientific knowledge in studying comorbidity syndrome in brain damage does not allow to fully identify the cause-and-effect relationship and, later on, to break the vicious circle of pathological changes. At the same time, specific mechanisms of comorbidity formation are known, which allows preventing comorbidity development at early stages [16].

The multimorbidity is closely related to the age of the patients. According to some authors [16], there are an average of 2.8 concurrent diseases per patient under 20 years of age, 3.2 diseases between 21 and 40 years of age, 4.5 diseases between 41 and 60, and 5.8 verified diagnoses between 60-75 years of age. Not only quantitative but also qualitative changes in multimorbidity occur with age. Atypical course of diseases is observed, latent course of disease with minimal clinical manifestations and slow evolution as well as no acute onset are also characteristic [17].

Different systems are used to assess multimorbidity depending on the purpose. These include the Cumulative Illness Rating Scale (CIRS) modified for the elderly (CIRS-G) [18], the KaplanFeinstein system for assessing multimorbidity in 
исследователи полагают, что полиморбидный синдром не может быть обусловлен случайным сочетанием наблюдаемых нарушений, а в основе полиморбидности лежит строгая иерархия механизмов, определяющих мозаику и единство патологических проявлений. В научной литературе наиболее широко представлены работы по полиморбидности в гериатрии, при сердечно-сосудистых заболеваниях желудочно-кишечного тракта, психических, неврологических и других заболеваниях [13, 14].

Тяжелые повреждения мозга с исходом в хроническое критическое состояние формируют особую клиническую модель пациента. Изменения в мозге после его повреждения при травме или заболевании сопровождаются функциональными и морфологическими изменениями во внутренних органах, которые создают основу для последовательного развития ряда коморбидных заболеваний [15]. Указанные изменения формируют порочный патологический круг, препятствующий стабилизации состояния и восстановления церебральных функций [16].

Недостаточность теоретической базы в изучении коморбидного синдрома при повреждениях головного мозга не позволяет в полной мере выявить причинно-следственную связь и, в дальнейшем, разорвать порочный круг патологических изменений. В тоже время, имеются сведения о конкретных механизмах формирования коморбидности, что позволяет на ранних этапах предотвратить дальнейшее развитие коморбидности [16].

Полиморбидность тесно связана с возрастом заболевших. По данным некоторых авторов [16] на одного пациента моложе 20 лет среднестатистически приходится 2,8 одновременно протекающих заболевания, в возрасте от 21 года до 40 лет - 3,2 заболевания, в возрасте от 41 года до 60 лет - 4,5 болезней, а в возрасте от 60-75 лет - 5,8 верифицированных диагнозов. С возрастом происходит не только количественное изменение полиморбидности, но и качественное. Наблюдается атипичное течение болезней, характерно латентное течение болезни с минимальными клиническими проявлениями и медленной клинической динамикой, а также отсутствие острого дебюта [17].

Для оценки полиморбидности в зависимости от поставленных задач используют различные системы. Среди них система Cumulative illness rating scale (CIRS), которая была модифицирована для пожилых людей (CIRS-G) [18]. Система Kaplan-Feinstein для оценки полиморбидности у онкологических пациентов [19]. Для прогноза летальности используют шкалу Charlson [20]. Также используется Index of coexistent disease (ICED), который наиболее cancer patients [19]. The Charlson scale is also used to predict mortality (20). The Index of co-existent disease (ICED) elaborated to estimate hospital length of stay and likelihood of repeated hospitalization [21] is also utilized.

\section{Comorbid Metabolic Disorders}

Brain damage leads to significant changes in metabolism presenting as a non-specific systemic response. The most important cause of metabolic disturbances besides changes in gastrointestinal tract is the hypermetabolic and hypercatabolic state.

Malnutrition can be caused by either insufficient supply of nutrients to the body (simple starvation) or increased catabolism (stress starvation) [22-24].

Damage results in both inflammation and metabolic stress response [25]. To achieve proper healing and functional recovery, a metabolic response is required, which necessitates nutritional therapy, especially when the patient is malnourished and the stress-inflammatory response persists. Recently, the negative effect of continuous calorie and protein deficiency on the outcome of patients with CCI has been shown again [26].

Any injury causes release of stress hormones and inflammatory cytokine mediators. The cytokine response to infection and trauma, so-called «systemic inflammatory response syndrome», has a significant effect on metabolism [27].

Catabolism of glycogen, fat and protein with the release of glucose, free fatty acids and amino acids will lead to the reduction of protein content in the body (especially muscle mass), abnormal healing and immune response [28].

Brain damage associates with increased levels of cortisol, catecholamines, and pro-inflammatory cytokines (IL-1, IL-6, IL-8, TNF- $\alpha$ ) persisting for several weeks [29].

In response to stress, glucose metabolism abruptly changes along with its regulatory homeostatic mechanisms [30].

Brain damage from injury or stroke leads to a significant increase in endogenous glucose production. A portion of glucose while being broken down continues to produce energy without oxygen (glycolysis) [31]. An increase in lactate level in brain tissue and cerebrospinal fluid occurs. The severity of hyperglycemia has been noted to correlate with the extent of brain damage, while the lactate concentration corresponds to the level of metabolism increase [30].

Due to the release of stress hormones, insulin secretion is suppressed, endogenous glucose production and insulin resistance increase. Abnormal carbohydrate metabolism (hyperglycemia) is accompanied by persistent hyperlipidemia [32] .

The evidence for the need to correct stress hyperglycemia has been obtained. Stress-induced hyperglycemia is considered as a factor intensifying 
широко используется для расчета длительности пребывания в стационаре и вероятности повторной госпитализации [21].

\section{Коморбидные нарушения метаболизма}

Повреждение головного мозга приводит к выраженным изменениям метаболизма, которые проявляются в виде неспецифической системной реакции в ответ на повреждение. Важнейшая причина трофических нарушений, кроме изменений в ЖКТ - изменения метаболизма с развитием синдрома гиперметаболизма-гиперкатаболизма.

Недостаточность питания может быть вызвана следующими причинами: либо недостаточным поступлением питательных веществ в организм (простое голодание), либо выраженным катаболизмом (стрессовое голодание) [22-24].

Повреждение приводит как в воспалению, так и к метаболической стрессовой реакции [25]. Для достижения надлежащего заживления и функционального восстановления необходим метаболический ответ, для которого требуется нутриционная терапия, особенно когда пациент недоедает, а стресс-воспалительная реакция продолжается. В последнее время было вновь показано отрицательное влияние длительного дефицита калорий и белков на исход пациентов в хроническом критическом состоянии [26].

Любая травма вызывает высвобождение гормонов стресса и медиаторов воспаленияцитокинов. Цитокиновый ответ на инфекцию и травму, так называемый «синдром системного воспалительного ответа», оказывает существенное влияние на обмен веществ [27].

Катаболизм гликогена, жира и белка с высвобождением глюкозы, свободных жирных кислот и аминокислот, приводит к уменьшению содержания белка (особенно мышечной массы), к проблемам заживления и иммунного ответа [28].

Повреждение головного мозга сопровождается повышением уровня кортизола, катехоламинов и провоспалительных цитокинов (ИЛ-1, ИЛ-6, ИЛ-8, ФНО- $\alpha$ ), которые остаются на высоком уровне в течение нескольких недель [29].

В ответ на стресс происходит резкое изменение метаболизма глюкозы вместе с регуляторными механизмами ее гомеостаза [30].

Повреждение головного мозга в результате травмы или нарушения мозгового кровообращения ведет к значительному увеличению производства эндогенной глюкозы. Часть глюкозы, разрушаясь, продолжает производить энергию без участия кислорода damaging processes such as hemorrhagic transformation of brain infarction, blood-brain barrier impairment, brain edema, intracellular acidosis [33]. There is evidence proving a link between the severity of hyperglycemia and the outcome of severe traumatic brain injury (TBI). Hyperglycemia of 9.4 $\mathrm{mmol} / \mathrm{l}$ has been found to correlate with 9-12 points on Glasgow Coma Scale, $11 \mathrm{mmol} / 1$ corresponded to a score of under 8 , and with values exceeding $13 \mathrm{mmol} / \mathrm{l}$, the chance of survival was extremely low [34].

Brain tissue damage develops both in hyperglycemia above $9 \mathrm{mmol} / \mathrm{l}$ and in a slight decrease in glucose concentration below normal values [35].

The protein loss due to increased catabolism in sepsis and severe trauma can reach 260 g per day. This corresponds to daily losses of over $1 \mathrm{~kg}$ of muscle tissue. In the absence of adequate nutrient support, the loss of muscle mass in a short period of time will make successful weaning and subsequent recovery of patient impossible. Loss of muscle tissue is an important limitation for functional recovery [36].

In this situation, specific amino acids, such as glutamine and branched amino acids, are the only substrates that can be used in peripheral and damaged tissue as an energy source. The amino acids released from muscle tissue can be used for the synthesis of acute phase proteins including albumin, fibrinogen, glycoproteins, complement factors, etc.

Fat stores play an important role in metabolism. Increased lipolysis is part of the metabolic response to a serious disease, regardless of its etiology, the amount of fatty acids released can exceed energy requirements.

Intense protein consumption, as a major source of endogenous glucose production, and the resulting protein-energy deficit lead to longer hospital stays, lower wound healing rates, and an increased risk of secondary infection [37].

Comparative clinical and biochemical studies conducted in 237 patients in chronic critical condition after cerebral accident, of which 128 patients were discharged with improvement and 109 died, showed that in $85 \%$ of cases the main cause of mortality was multiorgan failure, combined with proteinenergy deficit, suppurative and inflammatory complications, and sepsis. Increasing protein-energy deficit along with the suppurative and inflammatory complications was found to play a leading role in the adverse outcome occurrence. Further reduction of albumin and total protein levels was associated with anemia, renal failure, hepatic failure and multiorgan insuffficiency resistant to intensive care [38].

\section{Gastrointestinal Comorbidities}

Gastrointestinal tract diseases can be observed in patients with severe brain damage during the entire period following a cerebral accident. The 
(гликолиз), [31]. Происходит увеличение лактата в ткани мозга и спинно-мозговой жидкости. Отмечено, что выраженность гипергликемии соответствует тяжести повреждения мозга, а уровень лактата - степени повышения метаболизма [30].

На фоне выброса гормонов стресса происходит подавление секреции инсулина, нарастание продукции эндогенной глюкозы и увеличение невосприимчивости к инсулину. Нарушение углеводного обмена (гипергликемия) сопровождается развитием стойкой гиперлипидемией [32].

Получены доказательства в необходимости коррекции стрессорной гипергликемии. Стресс-индуцированная гипергликемия рассматривается как фактор, усиливающий повреждающие процессы: геморрагическую трансформацию инфаркта мозга, нарушение гематоэнцефалического барьера, развитие отека головного мозга, интрацеллюлярный ацидоз [33]. Есть сведения, доказывающие связь между выраженностью гипергликемии и исходом тяжелой черепно-мозговой травмы (ТЧМТ). Установлено, что гипергликемия 9,4 ммоль/л соответствует уровню сознания по ШКГ 9-12 баллов, 11 ммоль/л — менее 8 баллов, при значениях, превышающих 13 ммоль/л, шанс на выживание был крайне низким [34].

Повреждение головного мозга при гипергликемии наступает при превышении концентрации глюкозы выше 9 ммоль/л и ведет к повреждению мозговой ткани, также как и незначительное снижение концентрации глюкозы ниже нормальных значений [35].

Степень катаболизма белка при сепсисе и тяжелой травме может достигать 260 г в сутки. Это соответствует ежедневным потерям в размере более 1 кг мышечной ткани. При отсутствии полноценной нутритивной поддержки потеря мышечной массы за короткое время сделает невозможным перевод пациента на самостоятельное дыхание и его дальнейшее восстановление. Потеря мышечной ткани является важным препятствием для функционального восстановления [36].

В этой ситуации отдельные аминокислоты, такие, как глютамин и разветвленные аминокислоты, являются единственным субстратом, который может быть использован в периферических и поврежденных тканях в качестве источника энергии. Аминокислоты, высвобождаемые из мышечной ткани, могут быть использованы для синтеза белков острой фазы - альбумина, фибриногена, гликопротеинов, факторов комплемента и т.д.

Запасы жира играют важную роль в метаболизме. Ускорение темпов липолиза является частью метаболического ответа на тяжелое gastrointestinal tract is affected by concomitant gastroenterological diseases, hereditary predisposition, impaired swallowing, poor diet, infectious agents, lack of physical activity, horizontal position of the patient, fluid and electrolyte disorders, metabolic and neurological disturbances, presence of gastric tube or stoma, treatment with antibiotics and other drugs [39].

Mechanisms and sequence of pathological processes in gastrointestinal tract in brain damage have not been studied yet. However, there is data that the biologically active substances involved in the gastrointestinal disease development, such as gastrin and gastrin-like peptides, may be produced both in the brain and in the gut. In addition, the gastrointestinal microbiome has a great impact on the gastrointestinal tract [40].

Any brain damage can certainly be regarded as stress. The outcome of stress depends on the balance of strength and duration of the stress factor and the potential of body protective forces. Therefore, at the stage of exhaustion both full restoration of body functions and their failure (hypermetabolism and hypercatabolism with impaired protein, carbohydrate, lipid metabolism, increased consumption of carbohydrate and lipid stores, breakdown of tissue proteins, development of intestinal failure syndrome) are possible, especially on exposure to other adverse stress factors.

Studies performed on patients with severe injuries hospitalized in the intensive care unit (ICU) [41] showed that stress-induced gastric erosions were observed in $91.4 \%$ of patients, gastric and duodenal ulcers - in $36.2 \%$, upper gastrointestinal bleeding — in $27.6 \%$, intestinal motility disorders and diarrhea - in $43.1 \%$ of patients. The rate of GIT complications was even higher in patients on prolonged lung ventilation. Asymptomatic stress-related gastrointestinal mucosal damage was found in $74-100 \%$, diarrhea - in $15-51 \%$, reduced intestinal motility - in 50\%, gastric stasis - in 39\%, constipation - in 15\%, intestinal obstruction - in $4-10 \%$ of cases [42].

Gastrointestinal erosions and ulcers in ICU patients are caused by increased protein breakdown, reduced production of gastrointestinal mucosal cells, inappropriate enteral nutrition, medications, autonomic nervous system stress response, increased corticosteroid production in response to the triggers $[43,44]$.

An important role in the muscle-gut interaction is played by an increased secretion of glutamine in skeletal muscle proteolysis, which is an energy source for intestinal mucosa cells [45].

In ICU patients, the disease evolution, gastrointestinal function and lung ventilation adequacy are in constant dynamic interaction. General reduction in blood circulation of internal organs and local hypoperfusion of digestive system 
заболевание, независимо от его этиологии, количество освобождающихся жирных кислот может превышать потребности в энергии.

Выраженное потребление белка, как основного источника для производства эндогенной глюкозы и следующая за этим белковоэнергетическая недостаточность, приводят к увеличению продолжительности пребывания больного в стационаре, снижению скорости заживления ран, а также к увеличению риска вторичной инфекции [37].

Сравнительные клинико-биохимические исследования, проведенные у 237 пациентов в хроническом критическом состоянии после церебральной катастрофы, из которых 128 пациентов выписаны с улучшением и 109 умерли, показали, что в 85\% случаев основной причиной летальности явилась ПОН, сочетающаяся с БЭН, гнойно-воспалительными осложнениями и сепсисом. Было установлено, что в формировании неблагоприятного исхода, ведущая роль принадлежит нарастающей БЭН на фоне гнойно-воспалительных осложнений. Дальнейшее снижение альбумина и общего белка сочеталось с анемией, проявлениями почечно-печеночной и ПОН, резистентной к проводимой интенсивной терапии [38].

\section{Коморбидные заболевания ЖКТ}

Заболевания ЖКТ сопровождают пациента с тяжелым повреждением головного мозга в течение всего периода после церебральной катастрофы. На состояние ЖКТ оказывают влияние сопутствующие гастроэнтерологические заболевания, наследственная предрасположенность, нарушенное глотание, неправильное питание, инфекционные агенты, отсутствие физической активности, горизонтальное положение пациента, нарушение водно-электролитного баланса, обмена и нейронных связей, наличие желудочного зонда и гастростомы, лечение антибиотиками и другими препаратами [39].

До сих пор до конца не изучены механизмы развития и последовательность возникновения патологических процессов в ЖКТ при повреждениях головного мозга. В частности, есть сведения о том, что в головном мозге, как и в ЖКТ могут вырабатываться одни и те же биологически активные вещества, например, гастрин и гастриноподобоные пептиды, роль которых в патогенезе нарушений ЖКТ неоспорима. Кроме того, на состояние ЖКТ большое влияние оказывает микробиом кишечника [40].

Безусловно, любое поражение головного мозга можно рассматривать как стресс. Исход стресса зависит от соотношения силы и длительности действия стрессора и потенциальных возможностей защитных сил организма. appear to be the most significant mechanisms of negative impact of lung ventilation on gastrointestinal functional state $[46,47]$.

The gastrointestinal mucosa appears to be most vulnerable to microcirculation impairment part of the gut [48]. The structure of the intestinal mucosal vasculature allows bypassing of arterial blood with the stealing phenomenon in the distal part of intestinal villi even in stable hemodynamic parameters [49]. Compensatory spasm of local vessels persists for a long time even after hemodynamic stabilization [50]. Oxygen concentration in the vessels supplying the gastrointestinal mucosa decreases significantly due to severe hemodilution caused by absorption of the contents of the gut lumen [51]. Hematocrit can drop to as low as $10 \%$ in the intestinal capillary bed [42].

Reduced system and local hemodynamic parameters during lung ventilation with positive expiratory end pressure and increased vascular resistance lead to hypoxia and damage of gastric and intestinal mucosa, as well as to a slower rate of gastric emptying and a decrease in intestinal motility [52]. After 24 hours, erosive gastritis and gastric stress ulcers can be detected in $74-100 \%$ of ICU patients who had an episode of acute hypoxia [53]. Bleeding from pyloric and duodenal ulcers is massive and difficult to treat conservatively [54]. Studies show that in patients requiring long-term respiratory support, gastric bleeding occurs mostly during the first two weeks of lung ventilation [55].

Vomiting in the intensive care unit may be caused by infectious agents (S.aureus, B.cereus, Cl.perfringens, etc.), poor diet, upper GI erosions and ulcers, inflammatory GI diseases, drugs (cytostatics, narcotics, glycosides, euphylline), gastric outlet obstruction due to mechanical (peptic ulcer, etc.). and functional (medication-induced gastric paresis, postoperative, post-infectious) factors, small intestinal obstruction (mechanical and functional), psychogenic factors, CNS disorders (direct brain damage, stimulation of the «vomiting center», vestibular disorders, increased intracranial pressure, infections), visceral pain (peritonitis, pancreatitis, cholecystitis, myocardial infarction), metabolic and endocrine disturbances, bacterial overgrowth syndrome, autonomic nervous system disorders, psychotic reactions, hypokalemia.

Abnormal motility in ICU patients most often manifest as constipation, but diarrhea is also possible [55]. Diarrhea in intensive care patients may be caused by infectious agents, including $\mathrm{Cl}$. difficile, hypokalemia, pancreatic insufficiency, malnutrition, drugs (e. g., thiazide and thiazide-like diuretics, antibiotics), autonomic nervous system disorders, and abnormal gastric emptying and motility [56].

Diarrhea is observed in almost $50 \%$ of patients with prolonged ICU stay and is particularly 
Поэтому на стадии истощения возможно как полное восстановление функций организма, так и их срыв (гиперметаболизм-гиперкатаболизм с нарушением обмена белков, углеводов, липидов, усиленным расходом углеводнолипидных резервов, распадом тканевых белков, развитием синдрома кишечной недостаточности), особенно при воздействии других неблагоприятных стрессорных факторов.

Исследования, проведенные на пациентах с тяжелыми травмами, госпитализированных в отделения реанимации и интенсивной терапии (ОРИТ) [41], показали, что стресс-индуцированные эрозивные гастриты наблюдаются у 91,4\% пациентов, язвы желудка и двенадцатиперстной кишки - у 36,2\%, язвенные кровотечения - у 27,6\%, нарушения моторики кишечника, диарея - у 43,1\% процентов пациентов. Частота осложнений со стороны ЖКТ была еще более выражена у пациентов, находящихся на длительной искусственной вентиляции легких. Асимптомное стресс-обусловленное повреждение мукозного слоя ЖКТ встречается в 74-100\%, диарейный синдром в 15-51\%, ослабление перистальтики кишечника - в 50\%, наличие застоя в желудке - в 39\%, запоры - в 15\%, кишечная непроходимость в 4-10\% случаев [42].

Образованию эрозий и язв ЖКТ у пациентов в отделениях ОРИТ способствует повышенный распад белка, снижение синтеза клеток слизистой оболочки ЖКТ, неправильное энтеральное питание, прием препаратов, реакция вегетативной нервной системы (BНC) на стресс, повышенный синтез глюкокортикостероидов (ГКС) в качестве ответа на триггер $[43,44]$.

Во взаимодействии мускулатура-кишечник важное значение имеет повышенное выделение при протеолизе скелетной мускулатуры глутамина, который является источником энергии для клеток кишечной слизистой [45].

У пациентов ОРИТ динамика основного заболевания, функциональное состояние ЖКТ и адекватность искусственной вентиляции легких (ИВЛ) находятся в постоянном динамическом взаимодействии. Снижение параметров кровообращения внутренних органов в целом и локальная гипоперфузия пищеварительной системы представляются наиболее значимыми механизмами негативного влияния ИВЛ на функциональное состояние ЖКТ $[46,47]$.

Среди анатомических структур желудка и кишечника наиболее чувствительными к нарушениям микроциркуляции является мукозный слой [48].

Строение сосудистых сплетений слизистой оболочки ЖКТ допускает шунтирование артериальной крови с формированием феномена обкрадывания дистальной части ворсинок likely among patients requiring lung ventilation. One of the most common causes of diarrhea in intensive care patients is incorrect nasogastric tube feeding (12-25\% of all cases) [57]. A significant increase in the likelihood of diarrhea has been found if the rate of administration of a nutrient mixture exceeded $50 \mathrm{ml} /$ hour, as well as when using hyperosmolar mixtures [58].

Enteric feeding may cause such complications as constipation, delayed gastric emptying, diarrhea, vomiting, which may occur in $50 \%$ of patients on lung ventilation [59]. The latter is considered a risk factor for $\mathrm{Cl}$. difficile growth, can be very severe, and may cause both longer hospital stay (3 weeks on average) and death $[60,61]$

Patients in ICU may develop paradoxical diarrhea. When fecaloma develops, the patient's intestines dilate and secretion increases proximal to its location. The feces become loose and «bypass» the fecaloma. Therefore, elderly patients with diarrhea require a thorough examination of the abdomen, rectum, and if necessary, abdominal X-ray.

Intestinal obstruction in ICU patients is often due to infectious agents, inflammatory diseases of abdomen and sepsis, hypokalemia, dehydration, poor diet, mesenteric ischemia. Intestinal obstruction may be mechanical and functional (intestinal pseudoobstruction, brady- or akinetic bowel). In addition, these conditions, as well as pre-existent GI conditions may at any stage lead to multiorgan failure.

\section{Role of Microbiome in the Development of Comorbidity}

Interest in microbiome has increased dramatically over the past decade as its role in the pathogenesis of many diseases has been identified. Physiological effects of critical illness and clinical interventions in intensive care significantly alter microbiome. In turn, the microbiome can predict the susceptibility of patients to disease, whereas its changes could prevent or even modify the critical illness in experimental models and clinical trials [62].

The largest number of studies were conducted on intestinal microbiome. There are about 40 trillion microorganisms living in the intestine [63]. Under normal conditions, commensal (cohabiting) microbes help to support human health and play various roles in its maintenance. In various diseases, microbiome is altered and transformed into pathobiome (contributing to abnormal microbial growth) [64]. These changes are most prominent in the ICU patients, where the intestines have long been considered a driving force of critical illness $[65,66]$.

The critical illness significantly alters the physiology of the host, which in turn changes environmental conditions and the structure of the resident microbe community [67]. 
кишечника даже в условиях стабильной гемодинамики [49]. Компенсаторный спазм сосудов, располагающихся в нем, сохраняется долгое время даже после нормализации параметров гемодинамики [50]. Концентрация кислорода в сосудах, питающих мукозный слой ЖКТ, существенно снижается за счет выраженной гемодилюции, обусловленной абсорбцией содержимого из просвета кишечной трубки [51]. В капиллярном русле кишечника показатель гематокрита может снижаться до 10\% [42].

Снижение показателей системной и локальной гемодинамики в условиях ИВЛ с положительным давлением конца выдоха и повышенного сосудистого сопротивления приводит к гипоксии слизистой оболочки желудка и кишечника и повреждению ее целостности, а также к замедлению скорости опорожнения желудка и снижению перистальтической активности кишечника [52]. По истечении суток эрозивный гастрит и стрессорные язвы желудка выявляются уже у 74-100\% пациентов ОРИТ, имевших эпизод острой гипоксии [53]. Кровотечения из пилорических язв и из язв двенадцатиперстной кишки отличаются массивностью и трудно поддаются консервативному лечению [54]. Проведенные исследования показывают, что среди пациентов, нуждающихся в длительной респираторной поддержке, наибольшее число желудочных кровотечений наступает в течение первых двух недель ИВЛ [55].

Причинами рвоты у пациента в отделении реанимации могут быть: инфекционные агенты (токсины S.aureus, B.cereus, Cl.perfringens и др.), неправильное питание, эрозивно-язвенные поражения верхних отделов пищеварительного тракта, воспалительные заболевания ЖКТ, действие лекарственньх препаратов (цитостатики, наркотики, сердечные гликозиды, эуфиллин), непроходимость выходного отдела желудка механическая (язвенная болезнь и др.) и функциональная (вследствие пареза желудка, вызванного лекарствами, послеоперационная, послеинфекционная), непроходимость тонкой кишки (механическая и функциональная), психогенные факторы, нарушения ЦНС (непосредственное повреждение головного мозга, стимуляция «рвотного центра», вестибулярные расстройства, повышение внутричерепного давления, инфекции), висцеральная боль (перитонит, панкреатит, холецистит, инфаркт миокарда), метаболические и эндокринные факторы, синдром избыточного бактериального роста, вегетативные нарушения, психические реакции, гипокалиемия.

Нарушения моторики у пациентов в ОРИТ проявляются наиболее часто в виде акинезии, но возможен и диарейный синдром [55]. Диарея у реанимационных пациентов может быть вызвана инфекционными агентами, в том числе
Hypoperfusion and reperfusion of the intestinal wall lead to intense inflammation of the mucosa and a series of environmental changes. The increased concentration of nitrates [68] and the abnormal mucosal oxygen gradient in [69] promote the growth of microbes such as Proteobacteriaceae, which contain many clinically important gram-negative bacilli such as Pseudomonas aeruginosa and Escherichia coli, and some Firmicutes such as Staphylococcus aureus and Enterococcus spp. [70-72].

The main route of microbial migration into the gut is through the oropharynx. The catabolic starving in critical diseases leads to reduced migration of food bacteria and undernutrition of commensal (symbiotic) microbes [73]. In patients in critical illness healthy microbiome of the oral cavity is replaced by gram-negative aerobes, including significant Proteobacteriaceae [74, 75].

The upper gastrointestinal tract becomes a stagnating pool for potential pathogens, which heralds extra-abdominal infections and multiorgan failure [76]. The lower gastrointestinal tract, which in healthy individuals contains hundreds of different bacterial species, loses its diversity and contains only a few (in some cases single) bacterial species [77-79].

Microbiome is not restricted to the intestines, and several other body organs were also found to shelter microbes involved in a critical disease development. For example, a study comparing 15 patients requiring lung ventilation with healthy patients who had their lower respiratory tract sampled by bronchoscopy showed that the diversity of upper and lower respiratory tract microbiomes decreased during 24 hours after tracheal intubation and further declined over time [80].

Unlike the intestines, the alveolar space of a healthy person is an unfavorable environment for most bacteria [81]. An important reason for their low growth is the lack of nutrient substrate for bacterial metabolism. In pneumonia, the alveoli are filled with a protein-rich fluid favorable for microbial proliferation [82].

The etiology of microbiome changes in critical illness varies. Probable causes may be related to changes brought about by critical illness as well as to side effects of the treatment (antimicrobial medications, opiates, proton pump inhibitors, enteral feeding, etc.) [83, 84].

Low consciousness and sedation are known to blunt the coughing reflex, whereas endotracheal intubation and acute condition impair the mucociliary drainage [85].

Proton pump inhibitors reduce elimination of gastric microbiome [86] and increase the immigration of bacteria into the lungs [87].

Raising the head of the patient's bed reduces immigration of gastric microbiome into the lungs [88], but also inhibits expectoration [89]. 
Cl. difficile, гипокалиемией, панкреатической недостаточностью, нарушением питания, воздействием препаратов (например, диуретики тиазидного и тиазидоподобного ряда, антибиотики), неправильной функцией вегетативной нервной системы (BНC), нарушением моторноэвакуаторной функции (МЭФ) желудка [56].

Диарея наблюдается почти у 50\% пациентов, длительно находящихся на лечении в ОРИТ, и она особенно вероятна среди пациентов, нуждающихся в ИВЛ. Одной из наиболее распространенных причин диареи у пациентов в реанимации являются погрешности в проведении зондового энтерального питания (1225\% от всех случаев) [57]. Было обнаружено достоверное повышение вероятности возникновения диареи при скорости введения питательной смеси $>50$ мл/час, а также при использовании гиперосмолярных смесей [58].

Энтеральное питание может вызывать такие осложнения как запор, задержку опорожнения желудка, диарею, рвоту, которые могут возникать у 50\% пациентов с ИВЛ [59].

Проведение ИВЛ рассматривается как один из факторов риска для роста $\mathrm{Cl}$. difficile, может протекать очень тяжело и способно приводить не только к удлинению сроков госпитализации (в среднем на 3 недели), но и к смерти больного [60, 61].

У пациентов в ОРИТ возможно развитие парадоксальной диареи. Она заключается в том, что при наличии калового камня, проксимальнее его расположения происходит растяжение кишки и повышение секреции. Кал становится неоформленным и «обходит» препятствие, созданное каловым камнем. Поэтому у пожилых пациентов с синдромом диареи необходимо тщательное обследование живота, прямой кишки, а при необходимости следует произвести рентгенографию органов брюшной полости.

Кишечная непроходимость у пациентов ОРИТ зачастую обусловлена инфекционными агентами, воспалительными заболеваниями органов брюшной полости и сепсисом, гипокалиемией, недостаточной гидратацией, неправильным питанием пациента, ишемией брыжейки. Кишечная непроходимость может быть механической и функциональной (кишечная псевдообструкция, бради- или акинезия кишечника).

Кроме того, данные состояния, а также преморбид в виде сопутствующей гастроэнтерологической патологии может на любом этапе приводить к полиорганной недостаточности.

\section{Роль микробиома в формировании коморбидности}

Интерес к микробиому резко усилился в последнее десятилетие в связи с выявлением
The enteral feeding, used to meet metabolic needs, was developed without regard to its impact on microbiome [90].

Nowadays there are many strategies for microbiome management in the intensive care unit. These include probiotics, fecal microbial transplantation (FMT) and selective digestive tract decontamination (SDD). Each has shown both some promise and significant logistic and intellectual flaws. Probiotics are selective exogenous bacteria ingested by the host. Meta-analyses and numerous studies have shown their efficacy in reducing the severity of pneumonia associated with lung ventilation without any positive effect on treatment duration or mortality [91, 92].

Fecal microbial transplantation has been surprisingly successful in recurrent colitis caused by Clostridia difficile compared to oral vancomycin [93], but still is rarely used in clinical practice.

The selective digestive tract decontamination is performed with a combination of enteral and systemic antibiotics. This method has been found to be very effective: a meta-analysis of 30 studies showed that the selective digestive tract decontamination was associated with a significantly reduced mortality [94].

\section{Conclusion}

Comorbidity plays a pivotal role in prognosis in severe brain damage resulting in a chronic critical condition. The most common comorbidities include suppurative and inflammatory complications, gastrointestinal diseases, as well as disturbances caused by the hypermetabolic and hypercatabolic syndrome. In severe cases, comorbidities can transform into multiorgan failure, sepsis with subsequent death.

Identification of the cause-and-effect relationship in the complicated comorbidities will help to reveal the most significant causes of their occurrence. The latter include hypermetabolic and hypercatabolic syndrome with the development of protein and energy deficit, gastrointestinal comorbidities hampering the metabolic normalization even with adequate nutrition therapy, and microbiome modification affecting immunity, metabolism, intestinal barrier and other major functions.

The timely detection and correction of the comorbid conditions (particularly by controlling their key pathogenetic elements) will allow optimizing treatment and increasing the efficiency of rehabilitation in patients with severe brain damage.

его роли в патогенезе многих заболеваний. Физиологические эффекты критического заболевания и клинические вмешательства интенсивной терапии существенно изменяют микробиом. В свою очередь, микробиом пред- 
сказывает подверженность пациентов к заболеванию, а изменения микробиома предотвращали или изменяли критическую болезнь в экспериментальных моделях и при клинических испытаниях [62].

Наибольшее количество исследований было проведено при изучении микробиома кишечника. В кишечнике обитает около 40 триллионов микроорганизмов [63]. В обычных условиях комменсальные (совместно живущие) микробы способствуют укреплению здоровья человека и играют разнообразные роли в его поддержании. При различных заболеваниях микробиом изменяется и преобразуется в способствующий болезни микробиом (патобиом) [64]. Указанные изменения наиболее сильно выражены у пациентов в отделении интенсивной терапии (ОИТ), где кишечник долгое время считался «двигателем» критического заболевания [65, 66] .

Критическое заболевание существенно изменяет физиологию хозяина, которая в свою очередь изменяет условия окружающей среды и структуры сообщества резидентных микробов [67].

Гипоперфузия и реперфузия кишечной стенки приводят к интенсивному воспалению слизистой оболочки и каскаду изменений окружающей среды. Повышенная концентрация нитратов [68] и измененный градиент кислорода в слизистой оболочке [69] способствуют росту микробов типа Proteobacteriaceae, который содержит много клинически знакомых грамотрицательных палочек, таких как Pseudomonas aeruginosa и Escherichia coli, и некоторых членов типа Firmicutes, таких как золотистый стафилококк и Enterococcus spp. [70-72].

Основной путь миграции микробов в микробиом кишечника - через ротоглотку. Состояние катаболического голодания при критических заболеваниях приводит к снижению иммиграции пищевых бактерий и снижению питания комменсальных (микробов симбиоза) микробов [73]. У пациентов в критическом состоянии здоровый микробиом полости рта вытесняется грамотрицательными аэробами, в том числе видными представителями типа Proteobacteriaceae [74, 75].

Верхний отдел желудочно-кишечного тракта становится застойным резервуаром потенциальных патогенов, наличие которых является прогностическим признаком экстраабдоминальных инфекций и полиорганной недостаточности [76]. Микробиом нижнего отдела желудочно-кишечного тракта, который у здоровых людей содержит сотни различных видов бактерий, теряет разнообразие, и представлен несколькими (в некоторых случаях только одним) бактериальными видами [77-79].
Микробиом не ограничен кишечником, и несколько участков тела содержат микробы, которые были вовлечены в критическое заболевание. Например, исследование, в котором сравнивали 15 пациентов, нуждающихся в искусственной вентиляции легких, со здоровыми пациентами, у которых брали пробы нижних дыхательных путей с помощью бронхоскопии, показало, что разнообразие микробиома верхних и нижних дыхательных путей уменьшалось в течение 24 часов после интубации трахеи и далее уменьшалось с течением времени [80].

В отличие от кишечника, альвеолярное пространство у здорового человека является экологически неблагоприятной средой для большинства бактерий [81]. Важной причиной их низкого размножения является отсутствие питательного субстрата для бактериального метаболизма. При пневмонии альвеолы заполняются богатой белком жидкостью, благоприятной для размножения микробов [82].

Этиология изменений микробиома при критических заболеваниях разнообразна. Вероятные причины могут быть, связаны с изменениями, вызванными критическим состоянием, а также с побочными эффектами проводимой терапии (антимикробная терапия, опиаты, ингибиторы протонной помпы, энтеральное питание и др.) [83, 84].

Известно, что угнетенное сознание и седация притупляют кашлевой рефлекс, а эндотрахеальная интубация и острая болезнь ухудшают мукоцилиарный дренаж [85].

Ингибиторы протонной помпы снижают элиминацию микробиома желудка [86] и увеличивают иммиграцию бактерий в легкие [87].

Подъем изголовья кровати пациента уменьшает иммиграцию в легкие микробиома желудка [88], но также затрудняет отхождение мокроты из легких [89].

Энтеральное питание, используемое для удовлетворения метаболических потребностей, было разработано без учета его влияния на микробиом [90].

В настоящее время существует множество терапевтических стратегий для манипулирования микробиомом в отделении интенсивной терапии. К ним относятся пробиотики, фекальный микробный трансплантат (FMT) и селективная дезактивация пищеварительного тракта (SDD). Каждый из них показал некоторые перспективы, но каждый также имеет значительные проблемы как в логистическом, так и в интеллектуальном плане. Пробиотики - это селективные экзогенные бактерии, подаваемые хозяину. Мета-анализы и многочисленные исследования показали, что пробиотики эффективны для уменьшения выраженности 
пневмонии, связанной с вентиляцией легких, но не изменяют продолжительность лечения или летальность [91, 92].

Фекальный микробный трансплантат (FMT) оказался удивительно успешным при рецидивирующем колите, вызванном Clostridia difficile по сравнению с пероральным ванкомицином [93], однако редко применяемым в клинической практике.

Селективная деконтаминация пищеварительного тракта (SDD) осуществляется антибиотиками, вводимыми энтерально и в сочетании с системными антибиотиками. Установлено, что этот метод является очень эффективным, и при мета-анализе в 30 исследованиях отмечено, что применение SDD приводит к существенному снижению летальности [94].

\section{Заключение}

Коморбидность играет определяющую роль в прогнозе при тяжельх поражениях головного мозга с исходом в хроническое критическое состояние. Наиболее распространенными являются: гнойно-воспалительные осложнения, заболевания, связанные с деятельностью желудочно-кишечного тракта, а также трофиче-

\section{Литература}

1. Carson S.S. Definitions and Epidemiology of the Chronically Critically Ill, Respiratory Care. 2012; 57 (6): 848-858; DOI: 10.4187/respcare.01736

2. Carson S.S., Bach P.B. The epidemiology and costs of chronic critica illness. Crit Care Clin 2002; 18 (3): 461-476. DOI: 10.1016/S0749-0704 (02)00015-5

3. Смирнов Л.И. Патологическая анатомия и патогенез травматических заболеваний нервной системы; М.: Изд-во Акад. мед. наук СССР, 1947-1949.

4. Nelson J.E., Cox C.E., Hope A.A., Carson S.S. Chronic critical illness Am J Respir Crit Care Med 2010; 182 (4): 446-454.

5. White A.C., O'Connor H.H., Kirby K. Prolonged mechanical ventilation: review of care settings and an update on professional reimbursement. Chest 2008; 133 (2): 539-545 DOI: 10.1378/chest.07 0656

6. Nierman D.M., Nelson J.E. Chronic critical illness. Crit Care Clin 2002; 18 (3): xi-xii DOI: 10.1016/S0749-0704 (02)00017-9

7. Приказ МЗ РФ от 03.08.1999 n 303»О введение в действие отраслевого стандарта «протоколы ведения больных. Общие требования» Источник: http: //www.makhaon.com/index.php?lng $=$ ru\&p=dict\&cuid=14\&euph=\%CC\%EE\%E4\%E5\%EB\%FC+\%EF\%E0 $\% \mathrm{~F} 6 \% \mathrm{E} 8 \% \mathrm{E} 5 \% \mathrm{ED} \% \mathrm{~F} 2 \% \mathrm{E} 0$

8. Feinstein A.R. Pre-therapeutic classification of co-morbidity in chronic disease. Journal Chronic Disease. 1970; 23 (7): 455-468 DOI 10.1016/0021-9681 (70)90054-8

9. Kraemer H.C. Statistical issues in assessing comorbidity. Stat Med 1995; 14: 721-723. DOI: $10.1002 /$ sim. 4780140803

10. Van den Akker M., Buntinx F, Roos S., Knottnerus J.A. Comorbidity or multimorbidity: what's in a name? A review of the literature. Eur J Gen Pract. 1996; 2 (2): 65-70 DOI: 10.3109/13814789609162146

11. Лазебник Л. Б., Конев Ю. В., Дроздов В. Н., Ефремов Л. И. Полипрагмазия: гериатрический аспект проблемы. Consilium Medicum. 2007; 9 (12): 29-34

12. Митрофанов И.М., Николаев Ю.А., Долгова Н.А., Поспелова Т.И. Региональные особенности полимобидности в современной клинике внутренних болезней. Клин. мед. 2013; 6: 26-29.

13. Оганов Р. Г., Симаненков В. И., Бакулин И. Г., Бакулина Н. В., Барбараш О. Л., Бойцов С. А., Болдуева С. А., Гарганеева Н. П. Доцииин В. Л., Каратеев А. Е., Котовская Ю. В., Лила А. М., Лукьянов М. М., Морозова Т. Е., Переверзев А. П., Петрова М. М., Поздняков Ю. М., Сыров А. В., Тарасов А. В., Ткачева О. Н., Шальнова С. А. Коморбидная патология в клинической практике. Алгоритмы диагностики и лечения. Клинические рекомендации, Кардиоваскулярная терапия и профилактика. 2019; 18 (1): 5-66.

14. Misra U.K., Kalita J., Singh V.K., Kumar S. A study of comorbidities in myasthenia gravis. Acta Neurologica Belgica. 2019; 10: 1-6. DOI $10.1007 / \mathrm{s} 13760-019-01102-\mathrm{w}$ ские нарушения, обусловленные синдромом гиперметаболизма-гиперкатаболизма. В тяжелых случаях коморбидные заболевания переходят в полиорганную недостаточность, сепсис с последующим летальным исходом.

Выявление причинно-следственной связи в возникновении коморбидных осложнений позволит выделить наиболее значимые причины их возникновения. К последним следует отнести синдром гиперметаболизма-гиперкатаболизма с развитием белково-энергетической недостаточности, коморбидные заболевания жКТ, препятствующие нормализации обменных нарушений, даже при условии адекватной нутриционной терапии и изменения микробиома, от которого в огромной степени зависит иммунитет, обмен веществ, барьерная функция кишечного эпителия и ряд других важнейших функций.

Своевременное выявление и коррекция коморбидных состояний (особенно влияние на ключевые звенья их патогенеза) позволит оптимизировать лечение и повысить эффективность реабилитационных мероприятий у пациентов с тяжелыми повреждениями головного мозга.

References

1. Carson S.S. Definitions and Epidemiology of the Chronically Critically Ill, Respiratory Care. 2012; 57 (6): 848-858; DOI: 10.4187/respcare.01736

2. Carson S.S., Bach P.B. The epidemiology and costs of chronic critical illness. Crit Care Clin 2002; 18 (3): 461-476. DOI: 10.1016/S0749-0704 (02)00015-5

3. Smirnov L. I. Pathological anatomy and pathogenesis of traumatic diseases of the nervous system; Moscow,: Publishing house of the Academy of medical Sciences of the USSR, 1947-1949. [In Russ.]

4. Nelson J.E., Cox C.E., Hope A.A., Carson S.S. Chronic critical illness. Am J Respir Crit Care Med 2010; 182 (4): 446-454.

5. White A.C., O'Connor H.H., Kirby K. Prolonged mechanical ventilation: review of care settings and an update on professional reimbursement. Chest 2008; 133 (2): 539-545 DOI: 10.1378/chest.07-0656

6. Nierman D.M., Nelson J.E. Chronic critical illness. Crit Care Clin. 2002; 18 (3): xi-xii DOI: 10.1016/S0749-0704 (02)00017-9

7. Order of the Ministry of Health of the Russian Federation of 03.08.1999 n 303 «On the introduction of the industry standard» protocols for the management of patients. General requirements» Source: http: //www.makhaon.com/index.php?lng=ru\&p=dict\& cuid=14\& euph=\%CC\%EE\%E4\%E5\%EB\%FC+\%EF\%E0\%F6\%E8\%E5\%ED\%F2\%E0

8. Feinstein A.R. Pre-therapeutic classification of co-morbidity in chronic disease. Journal Chronic Disease. 1970; 23 (7): 455-468 DOI: 10.1016/0021-9681 (70)90054-8

9. Kraemer H.C. Statistical issues in assessing comorbidity. Stat Med. 1995; 14: 721-723. DOI: 10.1002/sim.4780140803

10. Van den Akker M., Buntinx F, Roos S., Knottnerus J.A. Comorbidity or multimorbidity: what's in a name? A review of the literature. Eur J Gen Pract. 1996; 2 (2): 65-70. DOI: 10.3109/13814789609162146

11. Lazebnik L. B., Konev Yu. V., Drozdov V. N., Efremov L.I. Polypragmasia: geriatric aspect of the problem.. Consilium Medicum. 2007; 9 (12): 29-34. [In Russ.]

12. Mitrofanov I.M., Nikolaev Yu.A., Dolgova N.A., Pospelova T.I. Regional features of polymobidity in the modern clinic of internal diseases. Clin.Med. 2013; 6: 26-29. [In Russ.]

13. Oganov R.G., Simanenkov V.I., Bakulin I.G., Bakulina N.V., Barbarash O.L., Bojtsov S.A., Boldueva S.A., Garganeeva N.P., Doshchicin V.L., Karateev A.E., Kotovskaya Yu.V., Lila A.M., Lukyanov M.M., Morozova T.E., Pereverzev A.P., Petrova M.M., Pozdnyakov Yu.M., Syrov A.V., Tarasov A.V., Tkacheva O.N., Shalnova S.A. Comorbid pathology in clinical practice. Diagnostic and treatment algorithms. Clinical guidelines. Kardiovaskulyarnaya terapiya i profilaktika. 2019; 18 (1): 5-66. [In Russ.]

14. Misra U.K., Kalita J., Singh V.K., Kumar S. A study of comorbidities in myasthenia gravis. Acta Neurologica Belgica. 2019; 10: 1-6. DOI: $10.1007 / \mathrm{s} 13760-019-01102-\mathrm{w}$ 


\section{Reviews}

15. Corral L., Javierre C.F., Ventura J.L., Marcos P., Herrero J.I., Mañez R. Impact of non-neurological complications in severe traumatic brain injury outcome. Crit Care. 2012 Dec 12; 16 (2): R44. DOI: 10.1186/cc11243.

16. Торосян E.A., Торосян А.Ц, Семерджян В.В. «Черная дыра» медицины - полиморбидность, Вестник медицинских технологий. 2008; 15 (1): 202-204

17. Брискин Б. С., Ломидзе О.В. Влияние полиморбидности на диагностику и исход в абдоминальной хирургии у пожилых. Клиническая геронтология, 2008; 4: 30-34.

18. Parmelee P.A., Thuras P.D., Katz I.R., Lawton M.P.Validation of the $\mathrm{Cu}$ mulative Illness Rating Scale in a geriatric residential population. $J$ Am Geriatr Soc. 1995; 43 (2): 130-137. DOI: 10.1111/j.15325415.1995.tb06377.x

19. Chaudhary R.K., Bhaduri D., Bhatia M., Hatti S., Ba R., Meva J. Influence of comorbidity in cancer surgery on treatment decisions, postoperative course and oncological outcome Asia Pac J Clin Oncol. 2013; 9 (1): 47-52. DOI: 10.1111/j.1743-7563.2012.01523.x

20. Chang Y.S., Huang J.S., Yen C.L., Wang C.H., Lai C.H., Wu T.H., Lan Y.J., Chang P.H., Yeh K.Y. The Charlson comorbidity index is an independent prognostic factor for treatment-naïve hepatocellular carcinoma patients with extrahepatic metastases hepatogastroenterology. 2015 62 (140): 1011-1015.

21. Imamura $K$, McKinnon $M$, Middleton $R$, Black $N$. Reliability of a comorbidity measure: the Index of Co-Existent Disease (ICED), J Clin Epidemiol. 1997; 50 (9): 1011-1016. DOI: 10.1016/S0895-4356 (97)00128-5

22. Попова Т.С., Шестопалов А.Е, Тамазашвили Т.Ш., Лейдерман И.Н. Нутритивная поддержка больных в критических ситуациях М., «М-Вести», 2002

23. Луфт В.М., Багненко С.Ф., Щербук Ю.А. (ред) Руководство по клиническому питанию. С-П. НИИ скорой помощи им. И. И. Джанелидзе, Санкт-Петербург, 2010

24. Соботка Л. Основы клинического питания» Материалы лекций для курсов Европейской ассоциации парентерального и энтерального питания, перевод с английского языка, «ИнтелТек», Петрозаводск, 2004

25. Soeters P., Bozzetti F, Cynober L., Elia M., Shenkin A., Sobotka L. Metaanalysis is not enough: the critical role of pathophysiology in determining optimal care in clinical nutrition. Clin Nutr, 2016; 35 : 748-757. DOI: 10.1016/j.clnu.2015.08.008

26. Yeh D.D., Fuentes E, QUrashi S.A., Cropano C., Kaafarani H., Lee J. King D.R., Demoya M.A., Fagenholz P.J., Butler K.L., Chang Y., Velmahos $G$. Adequate nutrition may get you home: effect of caloric/protein deficits on the discharge destination of critically ill surgical patients. $J$ Parenter Enteral Nutr. 2016; 40: 37-44. DOI: DOI 10.1177/0148607115585142

27. Grimble R.F Basics in clinical nutrition: Main cytokines and their effect during injury and sepsis. e-SPEN. the European e-Journal of Clinical Nutrition and Metabolism. 2008; 3: 289-292. DOI: 10.1016/j.eclnm.2008.07.002

28. Gillis C., Carli F. Promoting perioperative metabolic and nutritiona care. Anesthesiology, 2015; 123: 1455-1472. Alazawi W., Pirmadid N., Lahiri R., Bhattacharya S. Inflammatory and immune responses to surgery and their clinical impact. Ann Surg, 2016; 64: 73-80. DOI: 10.1097/ALN.0000000000000795

29. Рябов Г.А. Энергетический метаболизм при неотложныхсостояниях. Искусственное питание в неотложной хирургии и травматологии. М.: НИИ СП им. Н. В. Склифосовского. 2001: 21-82.

30. Тенедиева В.Д. Актуальные проблемы молекулярной медицинь в нейрохирургии (лабораторная практика и перспективные научные исследования. Клиническая лабораторная диагностика. 2007; 9: 23-24.

31. Sobotka L., Soeters P.B. Basics in clinical nutrition: Metabolic response to injury and sepsis. e-SPEN, the European e-Journal of Clinical Nutrition and Metabolism. 2009; 4: 1-3. DOI: 10.1016/j.eclnm.2008.07.005

32. Yamazaki Y., Harada S., Tokuyama S. Post-ischemic hyperglycemia exacerbates the development of cerebral ischemic neuronal damage through the cerebral sodium-glucose transporter. Brain research. 2012; 1489: 113-120. DOI: 10.1016/j.brainres.2012.10.020

33. Gilmore R.M., Stead L.G. The role of hyperglycemia in acute ischemic stroke. Neurocrit Care. 2006; 5 (2): 153-158. DOI: 10.1001/archneur.58.8.1209

34. Takanashi Y., Shinonaga M., Nakajama F. Relationship between hyperglycemia following head injury and neurological outcome. No To Shinkei. 2001: 53 (1):61-64.

35. Shi J., Dong B., Mao Y., Guan W., Cao J., Zhu R., Wang S. Review: Traumatic brain injury and hyperglycemia, a potentially modifiable risk factor. Oncotarget. 2016; 25; 7 (43): 71052-71061. DOI: 10.18632/oncotarget.11958

36. Soeters M.R., Soeters P.B., Schooneman M.G., Houten S.M., Rimijn J.A Adaptive reciprocity of lipid and glucose metabolism in human short-term starvation. Am J Physiol Endocrinol Metab. 2012; 303 : 1397-1407. DOI: 10.1152/ajpendo.00397.2012

37. Alipoor E., Mohammad Hosseinzadeh F., Hosseinzadeh-Attar M.J. Adipokines in critical illness: a review of the evidence and knowledge gaps. Biomed Pharmacother. 2018 Dec; 108: 1739-1750. DOI: 10.1016/j.biopha.2018.09.165.
15. Corral L., Javierre C.F, Ventura J.L., Marcos P., Herrero J.I., Mañez R. Impact of non-neurological complications in severe traumatic brain injury outcome. Crit Care. 2012 Dec 12; 16 (2): R44. DOI: $10.1186 / \mathrm{cc} 11243$

16. Torosyan E.A., Torosyan A.C, Semerdzhyan V.V. «Black hole» of medicine - polymorbidity. Vestnik medicinskih tekhnologij. 2008; 15 (1): 202-204. [In Russ.].

17. Briskin B.S., Lomidze O.V. Influence of polymorbidity on diagnosis and outcome in abdominal surgery in the elderly. Klinicheskaya gerontologiya.2008; 4: 30-34. [In Russ.].

18. Parmelee P.A., Thuras P.D., Katz I.R., Lawton M.P.Validation of the Cumulative Illness Rating Scale in a geriatric residential population. $J$ Am Geriatr Soc. 1995; 43 (2): 130-137. DOI: 10.1111/j.1 5325415.1995.tb06377.x

19. Chaudhary R.K., Bhaduri D., Bhatia M., Hatti S., Ba R., Meva J. Influence of comorbidity in cancer surgery on treatment decisions, postoperative course and oncological outcome Asia Pac J Clin Oncol. 2013; 9 (1): 47-52. DOI: 10.1111/j.1743-7563.2012.01523.x

20. Chang Y.S., Huang J.S., Yen C.L., Wang C.H., Lai C.H., Wu T.H., Lan Y.J., Chang P.H., Yeh K.Y. The Charlson comorbidity index is an independent prognostic factor for treatment-naïve hepatocellular carcinoma patients with extrahepatic metastases hepatogastroenterology. 2015; 62 (140): 1011-1015.

21. Imamura K., McKinnon M., Middleton R., Black N. Reliability of a comorbidity measure: the Index of Co-Existent Disease (ICED), J Clin Epidemiol. 1997; 50 (9): 1011-1016. DOI: 10.1016/S0895-4356 (97)00128-5

22. Popova T. S., Shestopalov A. E., Tamazashvili T. Sh., Leiderman I. N. Nutritional support of patients in critical situations M., "M-Vesti», 2002. [In Russ.]

23. Luft V.M., Bagnenko S.F., Serbuk J.A. (ed) Manual of clinical nutrition. $\mathrm{S}$-Pb. I.I. Dzhanelidze research Institute of emergency medicine, Saint Petersburg, 2010. [In Russ.].

24. Sobotka L. Fundamentals of clinical nutrition «Materials of lectures for courses of the European Association of parenteral and enteral nutrition, translated from English, «Inteltek», Petrozavodsk, 2004.[In Russ.]

25. Soeters P., Bozzetti F., Cynober L., Elia M., Shenkin A., Sobotka L. Metaanalysis is not enough: the critical role of pathophysiology in determining optimal care in clinical nutrition. Clin Nutr, 2016; 35: 748-757. DOI: 10.1016/j.clnu.2015.08.008

26. Yeh D.D., Fuentes E, QUrashi S.A., Cropano C., Kaafarani H., Lee J., King D.R., Demoya M.A., Fagenholz PJ., Butler K.L., Chang Y., Velmahos $G$. Adequate nutrition may get you home: effect of caloric/protein deficits on the discharge destination of critically ill surgical patients. J Parenter Enteral Nutr. 2016; 40: 37-44. DOI: DOI: 10.1177/0148607115585142

27. Grimble R.F Basics in clinical nutrition: Main cytokines and their effect during injury and sepsis. e-SPEN. the European e-Journal of Clinical Nutrition and Metabolism. 2008; 3: 289-292. DOI: 10.1016/j.eclnm.2008.07.002

28. Gillis C., Carli F. Promoting perioperative metabolic and nutritional care. Anesthesiology. 2015; 123: 1455-1472. DOI: 10.1097/ALN.0000000000000795

29. Ryabov G. A. Energy metabolism in emergency situations. Artificial nutrition in emergency surgery and traumatology. M.,: Research Institute of SPim. Named after N. V. Sklifosovsky. 2001: 21-82. [In Russ.].

30. Tenedieva V.D. Actual problems of molecular medicine in neurosurgery (laboratory practice and promising scientific research). Klinicheskaya laboratornaya diagnostika. 2007; 9: 23-24. [In Russ.].

31. Sobotka L., Soeters P.B. Basics in clinical nutrition: Metabolic response to injury and sepsis. e-SPEN, the European e-Journal of Clinical Nutrition and Metabolism. 2009; 4: 1-3. DOI: 10.1016/j.eclnm.2008.07.005

32. Yamazaki Y., Harada S., Tokuyama S. Post-ischemic hyperglycemia exacerbates the development of cerebral ischemic neuronal damage through the cerebral sodium-glucose transporter. Brain research. 2012; 1489: 113-120. DOI: 10.1016/j.brainres.2012.10.020

33. Gilmore R.M., Stead L.G. The role of hyperglycemia in acute ischemic stroke. Neurocrit Care. 2006; 5 (2): 153-158. DOI: 10.1001/archneur.58.8.1209

34. Takanashi Y, Shinonaga M., Nakajama F Relationship between hyperglycemia following head injury and neurological outcome. No To Shinkei., 2001; 53 (1): 61-64.

35. Shi J., Dong B., Mao Y., Guan W., Cao J., Zhu R., Wang S. Review: Traumatic brain injury and hyperglycemia, a potentially modifiable risk factor. Oncotarget. 2016; 25; 7 (43): 71052-71061. DOI: 10.18632/oncotarget.11958

36. Soeters M.R., Soeters P.B., Schooneman M.G., Houten S.M., Rimijn J.A. Adaptive reciprocity of lipid and glucose metabolism in human short-term starvation. Am I Physiol Endocrinol Metab. 2012; 303: 1397-1407. DOI: 10.1152/ajpendo.00397.2012

37. Alipoor E., Mohammad Hosseinzadeh F, Hosseinzadeh-Attar M.J. Adipokines in critical illness: A review of the evidence and knowledge gaps. Biomed Pharmacother. 2018 Dec; 108: 1739-1750. DOI: 10.1016/j.biopha.2018.09.165.

38. Parfyonov A.L., Petrova M.V., Stepanyuk T.A., Saidov Sh.H. Clinical and biochemical predictors of outcome in patients with post-comatose impairment of consciousness. Zhurnal nauchnyh statej «Zdorovie $i$ 
38. Парфенов А.Л., Петрова М.В., Степанюк Т.А., Саидов Ш.Х. Клинико-биохимические предикторы исхода у пациентов с посткоматозными нарушениями сознания. Журнал научных статей «Здоровье и образование в 21 веке». 2019, 21, 4: 44-50. DOI: 10.26787/nydha-2226-7425-2019-21-4

39. Levy H., Hayes J., Boivin M., Tomba T. Transpyloric feeding tube placement in critically ill patients using electromyogram and erythromycin infusion. Chest. 2004; 125 (2): 587-591. PMID: 14769742 DOI: $10.1378 /$ chest.125.2.587

40. Milla P.J. Inflammatory cells and the regulation of gut motility. $J P e$ diatr Gastroenterol Nutr. 2004; 39 (3): 750. DOI: 10.1097/00005176 200406003-00017

41. Foster J.A., Lyte M., Meyer E., Cryan J.F.Gut microbiota and brain function: an evolving field in neuroscience. Int. J. Neuropsychopharmacol. 2016; 19 (5): 114 DOI: 10.1093/ijnp/pyv114

42. Малхасян И.Э., Габриелян Л.М. Вторичные осложнения со стороны органов желудочно-кишечного тракта у травматологических больных. Медииинский Вестник Эребуни. 2010; 3 (43): 45-53.

43. Mutlu G.M., Mutlu E.A. Factor P. GI complications in patients receiving mechanical ventilation Chest. 2001; 119 (4): 1222-1241. DOI: $10.1378 /$ chest.119.4.1222

44. Lin C.C., Hsu Y.L., Chung C.S., Lee T.H. Stress ulcer prophylaxis in patients being weaned from the ventilator in a respiratory care center: A randomized control trial. J Formos Med Assoc. 2016; 115 (1): 19-24. DOI: $10.1016 /$ j.jfma.2014.10.006

45. Abunnaja S., Cuviello A., Sanchez J.A. Enteral and parenteral nutrition in the perioperative period: state of the art. Nutrients. 2013; 5 (2): 608-23. DOI: $10.3390 /$ nu5020608.

46. Del Guercio L.R.M. Factors for stress ulceration: sepsis, shock, hepatic failure. J. Crit. Illness. 2009; 73: 26-30.

47. Bartsch S., Bruning A., Reimann FM. Ludwig D. Haemodynamic ef fects of dopamine on postprandial splanchnic hyperaemia. Eur J. Clin. Invest. 2004; 34 (4): 268-274.

48. Bouadma L., Schortgen F., Ricard J.D., Martet G., Dreyfuss D., Saumon $\mathrm{G}$. Ventilation strategy affects cytokine release after mesenteric ischemia-reperfusion in rats. Crit Care Med., 2004; 32 (7): 1563-1569. DOI: 10.1097/01.CCM.0000129674.25259.D4

49. Bala M., Kashuk J., Moore E.E., Kluger Y., Biffl W., Gomes C.A., BenIshay O., Rubinstein C., Balogh Z.J., Civil I., Coccolini F., Leppaniemi A., Peitzman A., Ansaloni L., Sugrue M., Sartelli M., Di Saverio S., Fraga G.P., Catena F.Acute mesenteric ischemia: guidelines of the World Society of Emergency Surgery. World J Emerg Surg. 2017; 7; 12: 38. DOI 10.1186/s13017-017-0150-5

50. Lex D., Uhlig S. One-hit models of ventilator-induced lung injury: benign inflammation versus inflammation as a by-product. Anesthesiology. 2017; 126 (5): 909-922. DOI: 10.1097/ALN.0000000000001605

51. Jakob S.M. The effects of mechanical ventilation on hepato-splanchnic perfusion. Curr Opin Crit Care. 2010 Apr; 16 (2): 165-168. DOI: 10.1097/MCC.0b013e3283374b1c

52. Schwarte L.A., Schwartges I., Scheeren T.W., Schober P., Picker O. The differential effects of recombinant brain natriuretic peptide, nitroglycerine and dihydralazine on systemic oxygen delivery and gastric mucosal microvascular oxygenation in dogs. Anaesthesia. 2012; 67 (5): 501-507. DOI: 10.1111/j.1365-2044.2011.07047

53. Ospina-Tascón G.A., García Marin A.F. Echeverri G.J., Bermudez W.F. Madriñán-Navia H., Valencia J.D., Quiñones E., Rodríguez F., Marulanda A., Arango-Dávila C.A., Bruhn A., Hernández G., De Backer D. Effects of dobutamine on intestinal microvascular blood flow heterogeneity and $\mathrm{O}_{2}$ extraction during septic shock. J Appl Physiol (1985). 2017; 1; 122 (6): 1406-1417. DOI: 10.1152/japplphysiol.00886.2016

54. Whelan Ch.T., Kaboli P., Zhang Qi,, Siddique J., Ye S.,, Meltzer D.O. Upper gastrointestinal hemorrhage: have new therapeutics made a difference? J Hosp Med. 2009; 4 (7): 6-10. DOI: 10.1002/jhm.443

55. Herzig Sh J., Rothberg M.B., Feinbloom D.B., Howell M. D., Ho K. K. L., Ngo L.H., Marcantonio E. R. Risk factors for nosocomial gastrointestinal bleeding and use of acid-suppressive medication in non-critically ill patients. J Gen Intern Med. 2013; 28 (5): 683-690. DOI: 10.1007/s11606-012-2296-x

56. Cook D.J., Griffith L.E., Walter S.D., Guyatt G.H., Meade M.O., Heyland D.K., Kirby A., Tryba M.l. The attributable mortality and length of intensive care unit stay of clinically important gastrointestinal bleeding in critically ill patients. Crit Care. 2001; 5: 368-375. PMID: 11737927 PMCID: PMC83859 DOI: 10.1186/cc1071

57. Soto L.U, Ávila S.G., Alonso A.I.C., Mesones M.P.R., García A.M.A. De Lamadrid V.D. Clostridium difficile associated diarrhoea: An increased problem. Medicina Clínica (English Edition), 2016; 147 (12) 16: 543-546. DOI: 10.1016/j.medcli.2016.09.026

58. Lordani C.R.F, Eckert R.G., Tozetto A.G., Lordani T.V.A., Duarte P.A.D. The knowledge of intensive care professionals about diarrhea. Rev Bras Ter Intensiva. 2014; 26 (3): 299-304. DOI: 10.5935/0103507X.20140042

59. Seron-Arbeloa C., Zamora-Elson M., Labarta-Monzon L., Mallor Boneta T. Enteral Nutrition in Critical Care. J Clin Med Res. 2013; 5 (1): 1-11. DOI: 10.4021/jocmr1210w.

60. Atasever A. G., Ozcan P. E., Kasali K., Abdullah T., Orhun G., Senturk E. The frequency, risk factors, and complications of gastrointestina dysfunction during enteral nutrition in critically ill patients. Ther Clin Risk Manag. 2018; 14: 385-391. DOI: 10.2147/TCRM.S158492 obrazovanie $v 21$ veke». 2019, 21, 4: 44-50. [In Russ.]. DOI: 10.26787/nydha-2226-7425-2019-21-4

39. Levy H., Hayes J., Boivin M., Tomba T. Transpyloric feeding tube placement in critically ill patients using electromyogram and erythromycin infusion. Chest. 2004; 125 (2): 587-591. PMID: 14769742 DOI: $10.1378 /$ chest.125.2.587

40. Milla PJ. Inflammatory cells and the regulation of gut motility. J Pediatr Gastroenterol Nutr. 2004; 39 (3): 750. DOI: 10.1097/00005176200406003-00017

41. Foster J.A., Lyte M., Meyer E., Cryan J.F.Gut microbiota and brain function: an evolving field in neuroscience. Int. J. Neuropsychopharmacol. 2016; 19 (5): 114. DOI: 10.1093/ijnp/pyv114

42. Malhasyan I.E., Gabrielyan L.M. Secondary complications from the organs of the gastrointestinal tract in trauma patients. Meditsinskij Vestnik Erebuni. 2010; 3 (43): 45-53 [In Russ.].

43. Mutlu G.M., Mutlu E.A. Factor P. GI complications in patients receiving mechanical ventilation Chest. 2001; 119 (4): 1222-1241. DOI: $10.1378 /$ chest.119.4.1222

44. Lin C.C., Hsu Y.L., Chung C.S., Lee T.H. Stress ulcer prophylaxis in patients being weaned from the ventilator in a respiratory care center: A randomized control trial. J Formos Med Assoc. 2016; 115 (1): 19-24. DOI: 10.1016/j.jfma.2014.10.006

45. Abunnaja S., Cuviello A., Sanchez J.A. Enteral and parenteral nutrition in the perioperative period: state of the art. Nutrients. 2013; 5 (2): 608-23. DOI: $10.3390 /$ nu5020608

46. Del Guercio L.R.M. Factors for stress ulceration: Sepsis, shock, hepatic failure. J. Crit. Illness. 2009; 73: 26-30.

47. Bartsch S., Bruning A., Reimann F.M. Ludwig D. Haemodynamic effects of dopamine on postprandial splanchnic hyperaemia. Eur J. Clin. Invest. 2004; 34 (4): 268-274.

48. Bouadma L., Schortgen F, Ricard J.D., Martet G., Dreyfuss D., Saumon $\mathrm{G}$. Ventilation strategy affects cytokine release after mesenteric ischemia-reperfusion in rats. Crit Care Med., 2004; 32 (7): 1563-1569. DOI: 10.1097/01.CCM.0000129674.25259.D4

49. Bala M., Kashuk J., Moore E.E., Kluger Y., Biffl W., Gomes C.A., BenIshay O., Rubinstein C., Balogh Z.J., Civil I., Coccolini F., Leppaniemi A., Peitzman A., Ansaloni L., Sugrue M., Sartelli M., Di Saverio S., Fraga G.P., Catena F.Acute mesenteric ischemia: guidelines of the World Society of Emergency Surgery. World J Emerg Surg. 2017; 7; 12: 38. DOI: 10.1186/s13017-017-0150-5

50. Lex D., Uhlig S. One-hit models of ventilator-induced lung injury: benign inflammation versus inflammation as a by-product. Anesthesiology. 2017; 126 (5): 909-922. DOI: 10.1097/ALN.0000000000001605.

51. Jakob S.M. The effects of mechanical ventilation on hepato-splanchnic perfusion. Curr Opin Crit Care. 2010 Apr; 16 (2): 165-168. DOI: 10.1097/MCC.0b013e3283374b1c

52. Schwarte L.A., Schwartges I., Scheeren T.W., Schober P., Picker O. The differential effects of recombinant brain natriuretic peptide, nitroglycerine and dihydralazine on systemic oxygen delivery and gastric mucosal microvascular oxygenation in dogs. Anaesthesia. 2012; 67 (5): 501-507. DOI: 10.1111/j.1365-2044.2011.07047

53. Ospina-Tascón G.A., García Marin A.F., Echeverri G.J., Bermudez W.F, Madriñán-Navia H., Valencia J.D., Quiñones E., Rodríguez F., Marulanda A., Arango-Dávila C.A., Bruhn A., Hernández G., De Backer D. Effects of dobutamine on intestinal microvascular blood flow heterogeneity and $\mathrm{O}_{2}$ extraction during septic shock. J Appl Physio (1985). 2017; 1 ; 122 (6): 1406-1417. DOI: 10.1152/japplphysiol.00886.2016

54. Whelan Ch.T., Kaboli P., Zhang Qi,, Siddique J., Ye S.,, Meltzer D.O. Upper gastrointestinal hemorrhage: have new therapeutics made a difference? J Hosp Med. 2009; 4 (7): 6-10. DOI: 10.1002/jhm.443

55. Herzig Sh J., Rothberg M.B., Feinbloom D.B., Howell M. D., Ho K. K. L., Ngo L.H., Marcantonio E. R. Risk factors for nosocomial gastrointestinal bleeding and use of acid-suppressive medication in non-critically ill patients. J Gen Intern Med. 2013; 28 (5): 683-690. DOI: $10.1007 / \mathrm{s} 11606-012-2296-\mathrm{x}$

56. Cook D.J.,Griffith L.E.,Walter S.D., Guyatt G.H., Meade M.O., Heyland D.K., Kirby A., Tryba M.l. The attributable mortality and length of intensive care unit stay of clinically important gastrointestinal bleeding in critically ill patients. Crit Care. 2001; 5: 368-375. PMID: 11737927. PMCID: PMC83859. DOI: 10.1186/cc1071

57. Soto L.U, Ávila S.G., Alonso A.I.C., Mesones M.P.R., García A.M.A. De Lamadrid V.D. Clostridium difficile associated diarrhoea: An increased problem. Medicina Clínica (English Edition), 2016; 147 (12) 16: 543-546. DOI: 10.1016/j.medcli.2016.09.026

58. Lordani C.R.F., Eckert R.G., Tozetto A.G., Lordani T.V.A., Duarte P.A.D. The knowledge of intensive care professionals about diarrhea. Rev Bras Ter Intensiva. 2014; 26 (3): 299-304. Rev Bras Ter Intensiva. 2014 Jul-Sep; 26 (3): 299-304. DOI: 10.5935/0103-507X.20140042

59. Seron-Arbeloa C., Zamora-Elson M., Labarta-Monzon L., Mallor Boneta T. Enteral Nutrition in Critical Care. J Clin Med Res. 2013; 5 (1): 1-11. DOI: 10.4021/jocmr1210w.

60. Atasever A.G., Ozcan P. E., Kasali K., Abdullah T., Orhun G., Senturk E The frequency, risk factors, and complications of gastrointestinal dysfunction during enteral nutrition in critically ill patients. Ther Clin Risk Manag. 2018; 14: 385-391. DOI: 10.2147/TCRM.S158492

61. Chiang S-R., Lai C-C., Ho Ch.-H., Chen Ch-M., Chao Ch.-M., Wang JJ., Cheng $K$-Ch. Prolonged mechanical ventilation assistance inter- 
61. Chiang S-R., Lai C-C., Ho Ch.-H., Chen Ch-M., Chao Ch.-M., Wang J$J$., Cheng $\mathrm{K}$-Ch. Prolonged mechanical ventilation assistance interacts synergistically with carbapenem for clostridium difficile Infection in critically ill patients. J Clin Med. 2018; 7 (8): 224. DOI: $10.3390 / \mathrm{jcm} 7080224$

62. Archibald L.K., Banerjee S.N., Jarvis W.R. Secular trends in hospital-acquired Clostridium difficile disease in the United States, 1987-2001. J. Infect. Dis. 2004; 189 (9): 1585-1589. DOI: 10.1086/383045

63. Dickson R.P.The microbiome and critical illness. Lancet Respir Med. 2016; 4 (1): 72. Epub 2015 Dec 12. Review. DOI: 10.1016/S2213-2600 (15)00427-0. PMID: 26700442

64. Sender R., Fuchs S., Milo R. Are we really vastly outnumbered? revisiting the ratio of bacterial to host cells in humans. Cell. 2016; 164 (3): 337-340. DOI: 10.1016/j.cell.2016.01.013.

65. Alverdy J.C., Krezalek M.A. Collapse of the microbiome, emergence of the pathobiome, and the immunopathology of sepsis. Crit Care Med. 2017; 45 (2): 337-347. DOI: 10.1097/CCM.0000000000002172.

66. Fay K.T., Ford M.L., Coopersmith C.M. The intestinal microenvironment in sepsis. Biochim Biophys Acta Mol Basis Dis. 2017; 1863 (10 Pt B): 2574-2583. DOI: 10.1016/j.bbadis.2017.03.005

67. Klingensmith N.J., Coopersmith C.M. The gut as the motor of multiple organ dysfunction in critical illness. Crit Care Clin. 2016; 32 (2): 203-212. DOI: 10.1016/j.ccc.2015.11.004.

68. Adhikari N.K., Fowler R.A. Bhagwanjee S., Rubenfeld G.D. Critical care and the global burden of critical illness in adults. Lancet. 2010; 376 (9749): 1339-1346. DOI: 10.1016/S0140-6736 (10)60446-1.

69. Winter S.E., Winter M.G., Xavier M.N., Thiennimitr P., Poon V., Keestra A.M., Laughlin R.C., Gomez G., Wu J., Lawhon S.D., Popova I.E., Parikh S.J., Adams L.G., Tsolis R.M., StewartVJ, Bäumler AJ. Host-derived nitrate boosts growth of E. coli in theinflamed gut. Science. 2013; 339 (6120): 708-711. DOI: $10.1126 /$ science.1232467

70. Albenberg L., Esipova T.V., Judge C.P., Bittinger K., Chen J., Laughlin A., Grunberg S., Baldassano R.N., Lewis J.D., Li H., Thom S.R., Bushman F.D., Vinogradov S.A., Wu G.D. Correlation between intraluminal oxygen gradient and radial partitioning of intestinal microbiota. Gas troenterology. 2014; 147 (5): 1055-1063.e8. DOI: 10.1053/j.gastro.2014.07.020.

71. Lupp C., Robertson M.L., Wickham M.E., Sekirov I., Champion O.L. Gaynor E.C., Finlay B.B. Host-mediated inflammation disrupts the intestinal microbiota and promotes the overgrowth of Enterobacteriaceae. Cell Host Microbe. 2007; 2 (2): 119-129. DOI: 10.1016/j.chom.2007.06.010

72. Honda K., Littman D.R. The microbiome in infectious disease and inflammation. Annu Rev Immunol. 2012; 30: 759-795. DOI: 10.1146/annurev-immunol-020711-074937

73. Grootjans J., Lenaerts K., Derikx J.P., Matthijsen R.A., de Bruïne A.P., van Bijnen A.A., van Dam R.M., Dejong C.H., Buurman W.A. Human intestinal ischemia-reperfusion-induced inflammation characterized: experiences from a new translational model. Am J Pathol. 2010 176 (5): 2283-2291. DOI: 10.2353/ajpath.2010.091069.

74. David L.A., Maurice C.F, Carmody R.N., Gootenberg D.B., Button J.E., Wolfe B.E., Ling A.V., Devlin A.S., Varma Y., Fischbach M.A., Biddinger S.B., Dutton R.J., Turnbaugh P.J.. Diet rapidly and reproducibly alters the human gut microbiome. Nature. 2014; 505 (7484): 559-563. DOI: $10.1038 /$ nature 12820 .

75. Johanson W.G., Pierce A.K., Sanford J.P. Changing pharyngeal bacterial flora of hospitalized patients. Emergence of gram-negative bacilli. NEngl JMed. 1969; 281 (21): 1137-1140. DOI: 10.1056/NEJM196911202812101

76. Bahrani-Mougeot F.K., Paster B.J., Coleman S., Barbuto S., Brennan M.T., Noll J., Kennedy T., Fox P.C., Lockhart P.B. Molecular analysis of oral and respiratory bacterial species associated with ventilator-associated pneumonia. J Clin Microbiol. 2007; 45 (5): 1588-1593. DOI: 10.1128/JCM.01963-06

77. Marshall J.C., Christou N.V., Meakins J.L. The gastrointestinal tract. The «undrained abscess» of multiple organ failure. Ann Surg. 1993; 218 (2): 111-119

78. Zaborin A., Smith D., Garfield K., Quensen J., Shakhsheer B., Kade M., Tirrell M., Tiedje J., Gilbert J.A., Zaborina O., Alverdy J.C. Membership and behavior of ultra-low-diversity pathogen communities present in the gut of humans during prolonged critical illness. MBio. 2014; 5 (5): e01361-14. doi: 10.1128/mBio.01361-14.

79. Shimizu K., Ogura H., Hamasaki T., Goto M., Tasaki O., Asahara T. Nomoto K., Morotomi M., Matsushima A., Kuwagata Y., Sugimoto H. Altered gut flora are associated with septic complications and death in critically ill patients with systemic inflammatory response syndrome. Dig Dis Sci. 2011; 56 (4): 1171-1177. DOI: 10.1007/s10620010-1418-8

80. Madan J.C., Salari R.C., Saxena D., Davidson L., O'Toole G.A., Moore J.H., Sogin M.L., Foster J.A., Edwards W.H., Palumbo P., Hibberd P.L. Gut microbial colonisation in premature neonates predicts neonatal sepsis. Arch Dis Child Fetal Neonatal Ed. 2012; 97 (6): F456-462. DOI: 10.1136/fetalneonatal-2011-301373

81. Kelly B.J., Imai I., Bittinger K., Laughlin A., Fuchs B.D., Bushman F.D. Collman R.G. Composition and dynamics of the respiratory tract microbiome in intubated patients. Microbiome. 2016; 4: 7. DOI: 10.1186/s40168-016-0151-8

82. Dickson R.P., Erb-Downward J.R., Freeman C.M., McCloskey L., Beck J.M., Huffnagle G.B., Curtis J.L. Spatial Variation in the healthy human lungmicrobiome and the adapted island model of lung biogeogra- acts synergistically with carbapenem for clostridium difficile Infection in critically ill patients. J Clin Med. 2018; 7 (8): 224. DOI: $10.3390 / \mathrm{jcm} 7080224$

62. Archibald L.K., Banerjee S.N., Jarvis W.R. Secular trends in hospitalacquired Clostridium difficile disease in the United States, 1987-2001. J. Infect. Dis. 2004; 189 (9): 1585-1589. DOI: 10.1086/383045

63. Dickson R.P. The microbiome and critical illness. Lancet Respir Med. 2016; 4 (1): 72. Epub 2015 Dec 12. Review. DOI: 10.1016/S2213-2600 (15)00427-0. PMID: 26700442

64. Sender R., Fuchs S., Milo R. Are we really vastly outnumbered? revisiting the ratio of bacterial to host cells in humans. Cell. 2016; 164 (3): 337-340. DOI: 10.1016/j.cell.2016.01.013.

65. Alverdy J.C., Krezalek M.A. Collapse of the microbiome, emergence of the pathobiome, and the immunopathology of sepsis. Crit Care Med. 2017; 45 (2): 337-347. DOI: 10.1097/CCM.0000000000002172.

66. Fay K.T., Ford M.L., Coopersmith C.M. The intestinal microenvironment in sepsis. Biochim Biophys Acta Mol Basis Dis. 2017; 1863 (10 Pt B): 2574-2583. DOI: 10.1016/j.bbadis.2017.03.005

67. Klingensmith N.J., Coopersmith C.M. The gut as the motor of multiple organ dysfunction in critical illness. Crit Care Clin. 2016; 32 (2): 203-212. DOI: 10.1016/j.ccc.2015.11.004.

68. Adhikari N.K., Fowler R.A. Bhagwanjee S., Rubenfeld G.D. Critical care and the global burden of critical illness in adults. Lancet. 2010; 376 (9749): 1339-1346. DOI: 10.1016/S0140-6736 (10)60446-1.

69. Winter S.E., Winter M.G., Xavier M.N., Thiennimitr P., Poon V., Keestra A.M., Laughlin R.C., Gomez G., Wu J., Lawhon S.D., Popova I.E., Parikh S.J., Adams L.G., Tsolis R.M., Stewart VJ, Bäumler AJ. Host-derived nitrate boosts growth of E. coli in theinflamed gut. Science. 2013; 339 (6120): 708-711. DOI: 10.1126/science.1232467

70. Albenberg L., Esipova T.V., Judge C.P., Bittinger K., Chen J., Laughlin A., Grunberg S., Baldassano R.N., Lewis J.D., Li H., Thom S.R., Bushman F.D., Vinogradov S.A., Wu G.D. Correlation between intraluminal oxygen gradient and radial partitioning of intestinal microbiota. Gastroenterology. 2014; 147 (5): 1055-63.e8. DOI: 10.1053/j.gastro.2014.07.020.

71. Lupp C., Robertson M.L., Wickham M.E., Sekirov I., Champion O.L., Gaynor E.C., Finlay B.B. Host-mediated inflammation disrupts the intestinal microbiota and promotes the overgrowth of Enterobacteriaceae. Cell Host Microbe. 2007; 2 (2): 119-129. DOI: 10.1016/j.chom.2007.06.010

72. Honda K., Littman D.R. The microbiome in infectious disease and inflammation. Annu Rev Immunol. 2012; 30: 759-795. DOI: 10.1146/annurev-immunol-020711-074937

73. Grootjans J., Lenaerts K., Derikx J.P., Matthijsen R.A., de Brü̈ne A.P. van Bijnen A.A., van Dam R.M., Dejong C.H., Buurman W.A. Human intestinal ischemia-reperfusion-induced inflammation characterized: experiences from a new translational model. Am J Pathol. 2010; 176 (5): 2283-2291. DOI: 10.2353/ajpath.2010.091069.

74. David L.A., Maurice C.F, Carmody R.N., Gootenberg D.B., Button J.E., Wolfe B.E., Ling A.V., Devlin A.S., Varma Y., Fischbach M.A., Biddinger S.B., Dutton R.J., Turnbaugh P.J.. Diet rapidly and reproducibly alters the human gut microbiome. Nature. 2014; 505 (7484): 559-563. DOI: 10.1038 /nature 12820

75. Johanson W.G., Pierce A.K., Sanford J.P. Changing pharyngeal bacterial flora of hospitalized patients. Emergence of gram-negative bacilli. NEngl JMed. 1969; 281 (21): 1137-1140. DOI: 10.1056/NEJM196911202812101

76. Bahrani-Mougeot F.K., Paster B.J., Coleman S., Barbuto S., Brennan M.T., Noll J., Kennedy T., Fox P.C., Lockhart P.B. Molecular analysis of oral and respiratory bacterial species associated with ventilator-associated pneumonia. J Clin Microbiol. 2007; 45 (5): 1588-1593. DOI: 10.1128/JCM.01963-06

77. Marshall J.C., Christou N.V., Meakins J.L. The gastrointestinal tract. The «undrained abscess» of multiple organ failure. Ann Surg. 1993; 218 (2): 111-119.

78. Zaborin A., Smith D., Garfield K., Quensen J., Shakhsheer B., Kade M., Tirrell M., Tiedje J., Gilbert J.A., Zaborina O., Alverdy J.C. Membership and behavior of ultra-low-diversity pathogen communities present in the gut of humans during prolonged critical illness. MBio. 2014; 5 (5): e01361-14. DOI: 10.1128/mBio.01361-14.

79. Shimizu K., Ogura H., Hamasaki T., Goto M., Tasaki O., Asahara T., Nomoto K., Morotomi M., Matsushima A., Kuwagata Y., Sugimoto H. Altered gut flora are associated with septic complications and death in critically ill patients with systemic inflammatory response syndrome. Dig Dis Sci. 2011; 56 (4): 1171-1177. DOI: 10.1007/s10620010-1418-8

80. Madan J.C., Salari R.C., Saxena D., Davidson L., O'Toole G.A., Moore J.H., Sogin M.L., Foster J.A., Edwards W.H., Palumbo P., Hibberd P.L. Gut microbial colonisation in premature neonates predicts neonatal sepsis. Arch Dis Child Fetal Neonatal Ed. 2012; 97 (6): F456-462. DOI: 10.1136/fetalneonatal-2011-301373

81. Kelly B.J., Imai I., Bittinger K., Laughlin A., Fuchs B.D., Bushman F.D., Collman R.G. Composition and dynamics of the respiratory tract microbiome in intubated patients. Microbiome. 2016; 4: 7. DOI: 10.1186/s40168-016-0151-8

82. Dickson R.P., Erb-Downward J.R., Freeman C.M., McCloskey L., Beck J.M., Huffnagle G.B., Curtis J.L. Spatial Variation in the healthy human lungmicrobiome and the adapted island model of lung biogeography. Ann Am Thorac Soc. 2015; 12 (6): 821-830. DOI: 10.1513/AnnalSATS.201501-029OC 
phy. Ann Am Thorac Soc. 2015; 12 (6): 821-830. DOI: 10.1513/AnnalsATS.201501-0290C

83. Venkataraman A., Bassis C.M., Beck J.M., Young V.B., Curtis J.L., Huffnagle G.B., Schmidt T.M. Application of a neutral community model to assess structuring of the human lung microbiome. MBio. 2015; 6 (1). pii: e02284-14. DOI: 10.1128/mBio.02284-14.

84. Otani S., Chihade D.B., Coopersmith C.M. Critical illness and the role of the microbiome Acute Med Surg. 2018; 6 (2): 91-94. DOI: 10.1002/ams2.383. eCollection 2019

85. Akrami K., Sweeney D.A. The microbiome of the critically ill patient. Cur Opin Crit Care. 2018; 24 (1):49-54. DOI: 10.1097/MCC.0000000000000469.

86. Nakagawa N.K., Franchini M.L., Driusso P., de Oliveira L.R., Saldiva P.H., Lorenzi-Filho G. Mucociliary clearance is impaired in acutely ill patients. Chest. 2005; 128: 2772-2777. DOI: 10.1378/chest.128.4.2772

87. Lombardo L., Foti M., Ruggia O., Chiecchio A. Increased incidence of small intestinal bacterial overgrowth during proton pump inhibitor therapy. Clin Gastroenterol Hepatol. 2010; 8 (6): 504-508. DOI: 10.1016/j.cgh.2009.12.022.

88. Herzig S.J., Howell M.D., Ngo L.H., Marcantonio E.R. Acid-suppressive medication use and the risk for hospital-acquired pneumonia. JAMA. 2009; 301: 2120-2128. DOI: 10.1001/jama.2009.722

89. Drakulovic M.B., Torres A., Bauer T.T., Nicolas J.M., Nogué S., Ferrer M. Supine body position as a risk factor for nosocomial pneumonia in mechanically ventilated patients: a randomised trial. Lancet. 1999; 354 1851-1858. PMID: 10584721. DOI: 10.1016/S0140-6736 (98)12251-1

90. Li Bassi G., Zanella A., Cressoni M., Stylianou M., Kolobow T. Following tracheal intubation, mucus flow is reversed in the semirecumbent position: possible role in the pathogenesis of ventilator-associated pneumonia. Crit Care Med. 2008; 36: 518-525. DOI: 10.1097/01. CCM.0000299741.32078.E9

91. Schneider S.M., Le Gall P., Girard-Pipau F, Piche T., Pompei A., Nano J.L., Hébuterne X., Rampal P. Total artificial nutrition is associated with major changes in the fecal flora. Eur J Nutr. 2000; 39: 248-255. DOI: $10.1007 / \mathrm{s} 003940070003$

92. Zeng J., Wang C.T., Zhang F.S., Qi F., Wang S.F, Ma S., Wu T.J., Tian H., Tian Z.T., Zhang S.L., Qu Y., Liu L.Y., Li Y.Z., Cui S., Zhao H.L., Du Q.S., Ma Z., Li C.H., Li Y., Si M., Chu Y.F., Meng M., Ren H.S., Zhang J.C., Jiang J.J., Ding M., Wang Y.P. Effect of probiotics on the incidence of ventilator-associated pneumonia in critically ill patients: a randomized controlled multicenter trial. Intensive Care Med. 2016; 42 (6) 1018-1028. DOI: 10.1007/s00134-016-4303-x

93. Weng H., Li J.G., Mao Z., Feng Y., Wang C.Y., Ren X.Q., Zeng X.T. Probiotics for preventing ventilator-associated pneumonia in mechanically ventilated patients: a meta-analysis with trial sequential analysis. Front Pharmacol. 2017; 8: 717. DOI: 10.3389/fphar.2017.00717.

94. Quraishi M.N., Widlak M., Bhala N., Moore D., Price M., Sharma N. Iqbal T.H. Systematic review with meta-analysis: the efficacy of faecal microbiota transplantation for the treatment of recurrent and refractory Clostridium difficile infection. Aliment Pharmacol Ther. 2017; 46 (5): 479-493. DOI: $10.1111 /$ apt.14201.

95. Price R., Maclennan G., Glen J. Selective digestive or oropharyngeal decontamination and topical oropharyngeal chlorhexidine for prevention of death in general intensive care: systematic review and network meta-analysis. BMJ. 2014; 348: g2197 DOI: 10.1136/bmj.g2197.

Поступила 05.04.20
83. Venkataraman A., Bassis C.M., Beck J.M., Young V.B., Curtis J.L., Huffnagle G.B., Schmidt T.M. Application of a neutral community model to assess structuring of the human lung microbiome. MBio. 2015; 6 (1). pii: e02284-14. DOI: 10.1128/mBio.02284-14

84. Otani S., Chihade D.B., Coopersmith C.M. Critical illness and the role of the microbiome Acute Med Surg. 2018; 6 (2): 91-94. DOI: 10.1002/ams2.383. eCollection 2019

85. Akrami K., Sweeney D.A. The microbiome of the critically ill patient. Curr Opin Crit Care. 2018; 24 (1): 49-54. DOI: 10.1097/MCC.0000000000000469.

86. Nakagawa N.K. Franchini M. L. Driusso P de Oliveira L R., Saldiva P.H., Lorenzi-Filho G. Mucociliary clearance is impaired in acutely ill patients. Chest. 2005; 128: 2772-2777. DOI: 10.1378/chest.128.4.2772

87. Lombardo L., Foti M., Ruggia O., Chiecchio A. Increased incidence of small intestinal bacterial overgrowth during proton pump inhibitor therapy. Clin Gastroenterol Hepatol. 2010; 8 (6): 504-508. DOI: 10.1016/j.cgh.2009.12.022.

88. Herzig S.J., Howell M.D., Ngo L.H., Marcantonio E.R. Acid-suppressive medication use and the risk for hospital-acquired pneumonia. JAMA. 2009; 301: 2120-2128. DOI: 10.1001/jama.2009.722

89. Drakulovic M.B., Torres A., Bauer T.T., Nicolas J.M., Nogué S., Ferrer M. Supine body position as a risk factor for nosocomial pneumonia in mechanically ventilated patients: a randomised trial. Lancet. 1999; 354 1851-1858. PMID: 10584721. DOI: 10.1016/S0140-6736 (98)12251-1

90. Li Bassi G., Zanella A., Cressoni M., Stylianou M., Kolobow T. Following tracheal intubation, mucus flow is reversed in the semirecumbent position: possible role in the pathogenesis of ventilator-associated pneumonia. Crit Care Med. 2008; 36: 518-525. DOI: 10.1097/ 01.CCM.0000299741.32078.E9

91. Schneider S.M., Le Gall P., Girard-Pipau F, Piche T., Pompei A., Nano J.L., Hébuterne X., Rampal P. Total artificial nutrition is associated with major changes in the fecal flora. Eur J Nutr. 2000; 39: 248-255. DOI: $10.1007 / \mathrm{s} 003940070003$

92. Zeng J., Wang C.T., Zhang F.S., Qi F., Wang S.F., Ma S., Wu T.J., Tian H., Tian Z.T., Zhang S.L., Qu Y., Liu L.Y., Li Y.Z., Cui S., Zhao H.L., Du Q.S., Ma Z., Li C.H., Li Y., Si M., Chu Y.F, Meng M., Ren H.S., Zhang J.C., Jiang J.J., Ding M., Wang Y.P. Effect of probiotics on the incidence of ventilator-associated pneumonia in critically ill patients: a randomized controlled multicenter trial. Intensive Care Med. 2016; 42 (6): 1018-1028. DOI: 10.1007/s00134-016-4303-x

93. Weng H., Li J.G., Mao Z., Feng Y., Wang C.Y., Ren X.Q., Zeng X.T. Probiotics for preventing ventilator-associated pneumonia in mechanically ventilated patients: a meta-analysis with trial sequential analysis. Front Pharmacol. 2017; 8: 717. DOI: 10.3389/fphar.2017.00717.

94. Quraishi M.N., Widlak M., Bhala N., Moore D., Price M., Sharma N., Iqbal T.H. Systematic review with meta-analysis: the efficacy of faecal microbiota transplantation for the treatment of recurrent and refractory Clostridium difficile infection. Aliment Pharmacol Ther. 2017; 46 (5): 479-493. DOI: 10.1111/apt.14201.

95. Price R., Maclennan G., Glen J. Selective digestive or oropharyngeal decontamination and topical oropharyngeal chlorhexidine for prevention of death in general intensive care: systematic review and network meta-analysis. BMJ. 2014; 348: g2197 DOI: 10.1136/bmj.g2197. 